\title{
Historical Patterns of Inequality and Productivity around Financial Crises
}

\author{
Pascal Paul \\ Federal Reserve Bank of San Francisco
}

March 2022

Working Paper 2017-23

http://www.frbsf.org/economic-research/publications/working-papers/2017/23/

\section{Suggested citation:}

Pascal Paul. 2022. "Historical Patterns of Inequality and Productivity around Financial Crises," Federal Reserve Bank of San Francisco Working Paper 2017-23.

https://doi.org/10.24148/wp2017-23

The views in this paper are solely the responsibility of the authors and should not be interpreted as reflecting the views of the Federal Reserve Bank of San Francisco or the Board of Governors of the Federal Reserve System. 


\title{
Historical Patterns of Inequality and Productivity around Financial Crises
}

\author{
Pascal Paul \\ Federal Reserve Bank of San Francisco*
}

March 2022

\begin{abstract}
To understand the determinants of financial crises, previous research focused on developments closely related to financial markets. In contrast, this paper considers changes originating in the real economy as drivers of financial instability. To this end, I assemble a novel data set of long-run measures of income inequality, productivity, and other macrofinancial indicators for advanced economies. I find that rising top income inequality and low productivity growth are robust predictors of crises, and their slowmoving trend components largely explain these relations. Moreover, recessions that are preceded by such developments are deeper than recessions without such ex-ante trends.
\end{abstract}

Keywords: Financial Crises, Productivity, Income Inequality

JEL codes: E24, E44, E51, G1, G01, G20, H12, N10, N20

\footnotetext{
*I am particularly thankful for detailed comments by Adrien Auclert, John Fernald, Òscar Jordà, Christopher Meissner, Tyler Muir, Guillermo Ordoñez, Romain Rancière, Jae Sim (discussant), Alan Taylor, Gabriel Zucman, and two anonymous referees. I also thank Joseph Pedtke and Theodore Naff for excellent research assistance, a large number of researchers who have helped me with the individual country data, and many seminar participants for their insights at the 2018 Annual Meeting of the Society for Economic Dynamics, the Sixth CEPR Economic History Symposium, the Fall 2017 Macroeconomics System Committee Meeting of the Federal Reserve, and the Federal Reserve Bank of San Francisco. All errors are my own. The views expressed herein are solely those of the author and do not necessarily reflect the views of the Federal Reserve Bank of San Francisco or the Federal Reserve System. Email: pascal.paul@sf.frb.org.
} 
"The underlying performance of the broader economy before the crisis was troubling as well. Productivity growth was slowing, wages were stagnating, and the share of Americans who were working was shrinking. That put pressure on family incomes even as inequality rose and upward social mobility declined. The desire to maintain relative living standards no doubt contributed to a surge in household borrowing before the crisis."

Bernanke, Geithner, and Paulson (2018)

\section{Introduction}

The 2007-09 global financial crisis has been the defining event of economics in recent times, confronting economic research with challenging questions: Why do financial crises occur? Are they more likely to take place after particular macroeconomic developments? And, once a crisis breaks out, what determines the severity of the following recession?

To understand the macroeconomic determinants of crises, previous research has mainly focused on developments closely related to financial markets. For example, rapid growth in credit and stock prices are found to be robust early-warning indicators of crises (e.g., Schularick and Taylor, 2012; Kiley, 2021). The cyclical component is often found to account for the majority of the predictive power of these variables based on cycle-trend decompositions (e.g., Richter et al., 2021). Hence, the data speak towards the views of Kindleberger (1978) and Minsky (1986) that financial crises arise out of periods of speculative excesses and manias, associated with rapidly growing credit creation and asset prices.

In contrast to such temporary booms, the seeds of crises may also be sowed by slow-moving and persistent trends that originate in the real economy and that contribute towards a buildup of macrofinancial instability for many years. For example, as highlighted by the quote above, the U.S. economy experienced years of rising income inequality and low productivity growth leading up to the 2007-09 financial crisis (e.g., Piketty, Saez, and Zucman, 2018; Fernald, 2015). In this paper, I am interested in whether these U.S. patterns in fact reflect more general phenomena that tend to arise around a range of different financial crises in various countries. Because financial crises are infrequent events, a long-run historical approach is needed.

To this end, I combine and collect several data sets to create a new composite set of long-run measures of income inequality, productivity, and other macrofinancial indicators. First, from the Macrohistory Database by Jordà, Schularick, and Taylor (2017), I use several macrofinancial variables, such as aggregate credit measures, asset prices, and financial crises dates for 17 advanced economies from 1870 until 2013. Second, the Long-Term Productivity Database by Bergeaud, Cette, and Lecat (2016) provides measures of total factor productivity (TFP) and labor productivity (LP), covering the same set of countries with time series starting between 1870 and 1890 and available until 2013. 
Third, from the World Inequality Database, I add data for the income shares of the top 1\% and the top $10 \%$ of the income distribution. Among various measures of income inequality, these data have the longest coverage since they are based on historical tax income data. Nevertheless, the time series are available for fewer years than the productivity and the macrofinancial data. Moreover, when taking these data "off-the-shelf," the income shares for around half of the countries include capital gains, which are a part of the underlying tax income data. That is particularly problematic within the context of my paper, since capital gains induce substantial variation in the top income shares that is driven by asset price movements, as opposed to changes in saving of one part of the population relative to another, as explained in more detail below. To address this issue, I construct a new data set by carefully combining income inequality data that exclude capital gains from each of the country-specific sources.

Based on the merged data set, I obtain the following results. First, changes in the top income shares and productivity growth are strong predictors of financial crises. These results are robust to controlling for aggregate credit, a range of other macrofinancial variables, and various modifications of the baseline model, and they continue to hold for alternative financial crisis dates. Changes in the top $1 \%$ income share even slightly outperform credit in predicting crises. The same is the case for productivity growth on a post-World War II sample. Second, I show that these predictive relations are to a large extent explained by the trend component in each of the variables. That is, financial crises are typically preceded by slowly rising income inequality and years of low productivity growth. Third, I find that trends in top income inequality and productivity affect not only the likelihood of crises but also the recovery period. Recessions that are preceded by unusually strong increases in top income shares or low productivity growth are characterized by stronger declines in output compared with recessions without such ex-ante trends.

My findings have important implications for macrofinancial modeling. First, economies that experience prolonged periods of low productivity growth and rising income inequality may be more fragile and exposed to a financial crash. Accordingly, a buildup of risk occurs at a lower frequency than in conventional business cycle models, which generally capture high-frequency movements around a trend. The findings therefore suggest that current macrofinance models need to reexamine how to model systemic risk by allowing for lower frequency fluctuations to influence financial instability. The vast majority of the current macrofinance models do not allow for such channels, but typically analyze the impact of transitory shocks on financial stability. One notable exception is Cairó and Sim (2020) who show that the rise in the market power of U.S. firms over the last decades can replicate secular trends in labor and profit shares, income and wealth inequalities, household leverage, and the associated financial instability.

Related Literature. Morelli and Atkinson (2015) and Rajan (2010), among others, note the potential impact of changes in income inequality on financial crises. Kumhof, Rancière, and Winant (2015) put forth a theoretical explanation for why this may be the case. All else being equal, after an increase in income inequality, wealthy individuals may lend their unused income to less 
wealthy individuals who can in turn support their own consumption. However, increased credit intermediation and the lower income of poorer households may raise the likelihood of default and the risk of a crisis. ${ }^{1}$ Bordo and Meissner (2012) test for this channel by estimating the response of credit to changes in income inequality and find no evidence. However, Perugini et al. (2016) arrive at the opposite conclusion using a different sample and empirical specifications. Of course, both papers face the challenge of identifying truly exogenous changes of income inequality, which may explain their opposing findings and any differences with the ones in this paper. Moreover, if income inequality is a systematic determinant of crises, then changes in income inequality should precede and predict crises. This is the idea in Kirschenmann, Malinen, and Nyberg (2016) and in this paper. Kirschenmann et al. (2016) show that changes in the top income shares contain relevant information to directly predict financial crises.

However, none of the mentioned papers exclude capital gains from the income inequality measures, which induce large and volatile changes in the income shares as shown below. Since the related assets, in particular stocks, are typically held by people at the very top of the distribution, such movements simply reflect asset price effects and not an increase in saving of one part of the population. It is therefore unclear whether any of the previous findings-in favor or against a relation between income inequality and financial crises-are driven by asset price movements instead. Based on the income share data that I collect, I find that changes in the top income shares are strong crises predictors, and I can exclude the possibility that these are simply asset price effects.

Consistent with the findings in this paper, Mian, Straub, and Sufi (2020) study changes in household saving and borrowing over the past decades in the United States. Using a combination of aggregate and state-level data, they show that the rise in income inequality since 1980 has generated a large increase in saving by the rich that ended up as borrowing of non-rich households, which can be explained by a higher propensity to save out of permanent income changes by wealthier households (Mian, Straub, and Sufi, 2021). Their findings and the ones in this paper resonate with the views in Mian and Sufi (2018) to study the initial triggers that spark credit booms which lead to financial crises.

When considering the impact of productivity growth on financial instability, it is useful to distinguish between its role during the years leading up to a crisis and immediately around the outbreak of a crisis. As shown below (see Figure 5), across various countries, productivity growth is typically depressed around the outbreak of a crisis-either being the ultimate trigger of a crisis itself or the result of a trigger. This evidence is also confirmed by Gorton and Ordoñez (2020), who show that credit booms that end in a crisis are associated with lower productivity growth.

The fact that productivity growth is strongly depressed around the start of a crisis is also reflected in the vast majority of existing macro-finance models. Most models consider transitory

\footnotetext{
${ }^{1}$ Based on Kumhof et al. (2015), Cairó and Sim (2018) study the impact of monetary policy on financial stability.
} 
exogenous shocks to the productive capacity of firms - for example, in the form of technology or capital efficiency shocks (e.g., Brunnermeier and Sannikov, 2014; Gertler and Kiyotaki, 2010; He and Krishnamurthy, 2019). Generally, a negative shock of this type increases financial fragility. Within a few recent models, systemic risk can also increase after an initial positive innovation or a sequence of positive shocks (e.g., Boissay, Collard, and Smets, 2016; Gorton and Ordoñez, 2020; Paul, 2020). ${ }^{2}$ However, the typical trigger of a crisis in these models is again an adverse shock. In contrast to the behavior of productivity around the outbreak of a crisis, the empirical results in this paper show that low productivity growth typically precedes financial crises. In addition, I demonstrate that it is the trend component that accounts for this relation. Hence, years of low trend growth signal a financial crash in the near future.

Previous research has mainly focused on changes of "financial" factors in explaining the occurrence of financial crises in the near future, such as movements in credit (e.g., Schularick and Taylor, 2012; Mueller and Verner, 2021), aggregate stock and house prices (e.g., Borio and Lowe, 2002; Anundsen, Gerdrup, Hansen, and Kragh-Sørensen, 2016; Kiley, 2021), and external deficits (e.g., Davis et al., 2016; Kiley, 2021). 3,4 With respect to the empirical setup, most papers consider simple (percentage) changes in the explanatory variables. A few papers have attempted to remove trend changes beforehand (e.g., Dell'Ariccia et al., 2016; Richter, Schularick, and Wachtel, 2021). I show that such a procedure is indeed justified for stock prices and the current account, since the cyclical component endows these variables with their predictive power. By contrast, for income inequality and productivity, but also for credit and house prices, removing the trend would throw away valuable information. In this regard, the paper echoes the views by Comin and Gertler (2006).

Substantial evidence suggests that bank credit expansions play a particular role with respect to financial crises. Using data on bank equity prices, Baron and Xiong (2017) argue that such credit expansions are driven by waves of optimism. Krishnamurthy and Muir (2017) show that credit spreads are unusually low in the run-up phase to a crisis and that a change in credit spreads around financial crises forecasts well the subsequent severity. Apart from credit and credit spreads, other indicators of crises have been studied recently; for example, government popularity is found to predict crises (Herrera, Ordoñez, and Trebesch, 2020). With respect to the aftermath, Romer and Romer (2018) show that monetary and fiscal policy space prior to financial distress affects the decline in output following a crisis, and Jordà et al. (2013) obtain similar results with respect to pre-crisis credit booms.

\footnotetext{
${ }^{2}$ Cao and L'Huillier (2018) show that the Great Depression, the Japanese slump of the 1990s, and the Great Recession were each preceded by a technological revolution. Mendoza and Terrones (2014) find evidence that credit booms are more frequent after periods of productivity gains, particularly in industrialized countries.

${ }^{3}$ The focus of this paper is on the statistical predictive power of certain variables for the likelihood and severity of recessions in the near future. This is in contrast to other parts of the literature that have either looked at the typical behavior of variables around crises or used contemporaneous movements of variables to explain financial crises (e.g., Demirgüç-Kunt and Detragiache, 1998).

${ }^{4}$ One exception is Kaminsky and Reinhart (1999), who considered a range of predictor variables. However, productivity growth and income inequality were not among those.
} 
Road Map. The next section describes the data. Section 3 is separated into two parts. First, I study the predictive power of top income inequality for financial crises, and second, that of productivity. Based on the results, Section 4 considers the decomposition into trend and cycle. Section 5 collects the results on the aftermath of financial crises. Section 6 concludes.

\section{Data}

The data used for this analysis rely on three data sets that have been collected and made available recently. These are the Macrohistory Database, the Long-Term Productivity Database, and the World Inequality Database. ${ }^{5}$

\subsection{Macro-Financial Data}

The macro-financial data come from the Jorda-Schularick-Taylor Macrohistory Database (Jordà et al., 2017). This annual data set covers the years 1870-2013 and includes the following advanced economies: Australia, Belgium, Canada, Denmark, Finland, France, Germany, Italy, Japan, the Netherlands, Norway, Portugal, Spain, Sweden, Switzerland, the United Kingdom, and the United States. ${ }^{6}$ For these countries, the data set contains information on a number of macroeconomic and financial variables, such as GDP, consumption, investment, bank credit, mortgage lending, the current account, interest rates, and price indices (consumer, housing, stocks), among others. The house price data are based on Knoll, Schularick, and Steger (2017).

The database also incorporates indicators of financial crises events (see Appendix Table A.1). Using a wide variety of sources, financial crises are identified as "events during which a country's banking sector experiences bank runs, sharp increases in default rates accompanied by large losses of capital that result in public intervention, bankruptcy, or forced merger of financial institutions" (Schularick and Taylor, 2012). Figure 1 summarizes these dates graphically by showing the threeyear moving sum of the share of countries within a financial crisis. ${ }^{7}$

Noticeable episodes are the Great Depression around 1930 and the Great Recession around 2008both affected the majority of advanced economies. In contrast, coming out of World War II, most developed countries did not experience financial crises for around 30 years. To identify recessions, I follow the same methodology as Jordà et al. (2013). They use the Bry and Boschan (1971) algorithm to determine local minima and maxima in real GDP to distinguish troughs and peaks. If a financial crisis occurs within the neighborhood of a business cycle peak ( \pm 2 years), then the following recession is defined as a "financial recession." The remaining recessions are termed "nonfinancial recessions." Appendix Table A.2 lists all business cycle peaks.

\footnotetext{
${ }^{5}$ All three databases are publicly available (versions used are in parentheses): Macrohistory Database (release 2), World Inequality Database (August 2018), Long-Term Productivity Database (version 2.0).

${ }^{6}$ For the following analysis, I exclude war periods (World War I \& II).

${ }^{7}$ Accordingly, a country is in a financial crisis in year $t$ if the binary crisis-indicator is equal to one in year $t$ or $t \pm 1$.
} 


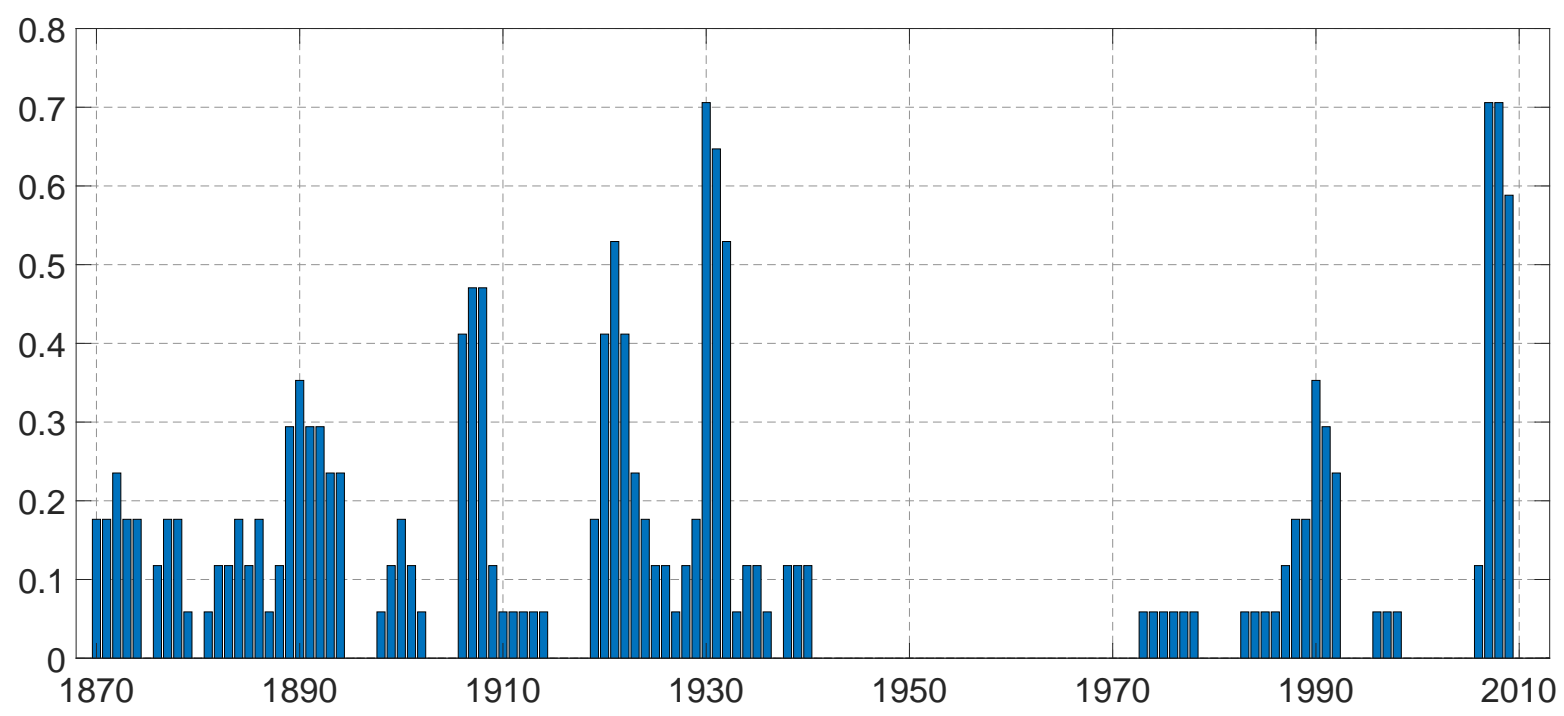

Figure 1: Share of Countries in Financial Crisis.

\subsection{Productivity Data}

Data on total factor productivity and labor productivity are obtained from the Long-Term Productivity Database by Bergeaud et al. (2016). This data set covers the same 17 advanced economies as the macro-financial database with time series starting between 1870 and 1890 . TFP is calculated as the Solow residual $A_{t}$ from a constant returns-to-scale Cobb-Douglas production function

$$
Y_{t}=A_{t} K_{t}^{\alpha} H_{t}^{1-\alpha}
$$

where $Y_{t}$ denotes real GDP, $K_{t}$ the capital stock, and $H_{t}$ total hours worked. $K_{t}$ is the sum of equipment and buildings and is derived by applying the perpetual inventory method to investment data on each of these components. ${ }^{8}$ Bergeaud et al. (2016) assume that the capital share $\alpha$ is equal to 0.3 . Labor productivity is defined as the ratio of GDP to total hours worked $Y_{t} / H_{t}$. Given these derivations, potential concerns regarding the accuracy of the productivity measures remain. First, the baseline estimates do not adjust for the time-varying utilization of capital and labor. To account for this potential shortcoming, I construct a measure of utilization-adjusted TFP following Imbs (1999), which is used in the following regressions (see Appendix A.2 for details). Second, the series do not account for long-run changes in the quality of capital and labor. However, in the following regressions, I consider growth rates over four years, and such long-run trends are therefore unlikely to bias the results.

Figure 2 shows how productivity growth has evolved over time, plotting percentiles in the distribution of the ten-year moving average labor productivity growth across all countries. ${ }^{9}$ Starting in the late nineteenth century, productivity growth was relatively stable, followed by the roaring twenties, and the collapse around the Great Depression. The developed world experienced

\footnotetext{
${ }^{8}$ Bergeaud et al. (2016) assume that equipment depreciates at an annual rate of $10 \%$ and buildings at $2.5 \%$. $K_{t}$ is the capital stock installed at the end of period $t-1$.

${ }^{9}$ The related figure for utilization-adjusted TFP is shown in Appendix A.2.
} 


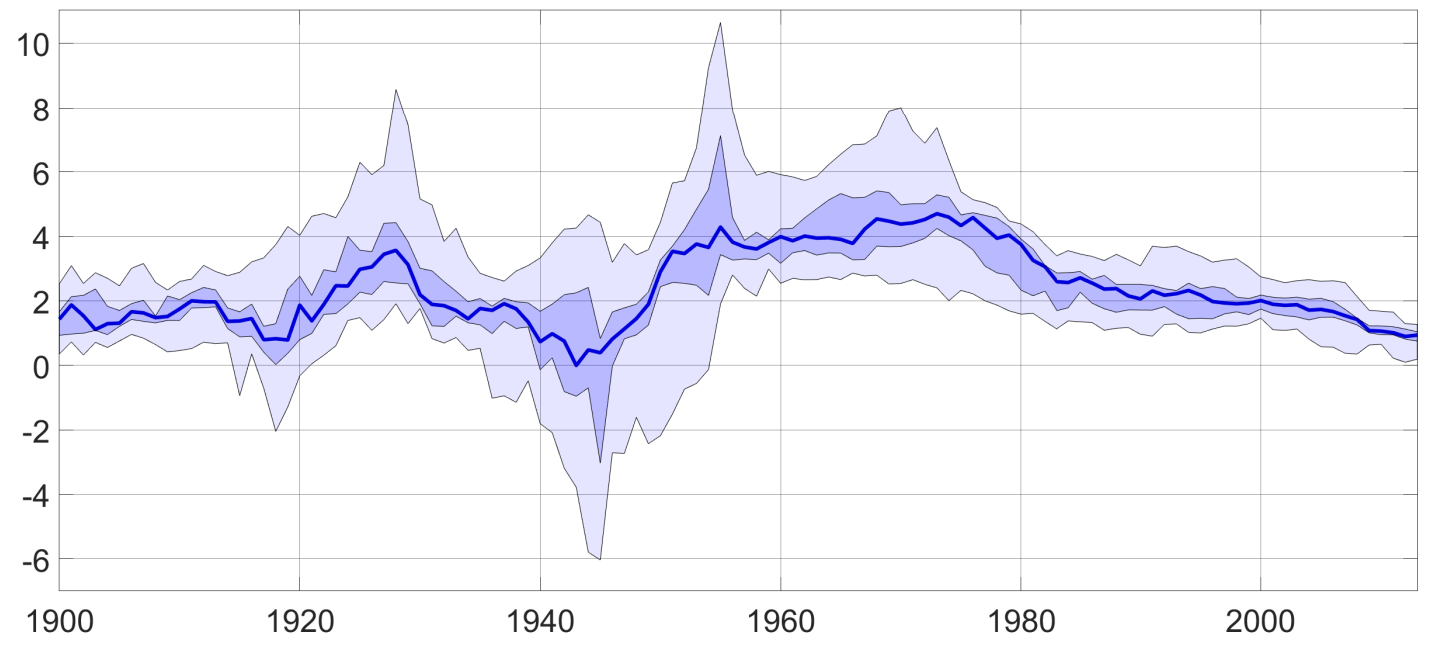

Figure 2: Ten-Year Moving Average of Labor Productivity Growth. Median, $33^{\text {rd }}, 66^{\text {th }}$, 90 ${ }^{\text {th }}$, and $10^{\text {th }}$ percentiles shown.

unprecedented productivity growth for around 35 years after World War II-a period that is also associated with few financial crises (see Figure 1). More recently, productivity growth has slowed down significantly. Overall, there is substantial cross-country heterogeneity throughout the sample. $^{10}$

\subsection{Income Inequality Data}

I use pretax income share data from the World Inequality Database to measure income inequality. Income shares describe the fraction of total income that accrues to a certain percentile of the income distribution. These data are constructed using a variety of sources, in particular tax income data. An important issue that arises within the context of my paper is the treatment of realized capital gains that can be part of the income based on income tax data. Depending on the tax system in place, citizens may have to pay taxes on their revenues from selling certain assets, in particular stocks. Using top income shares based on data that includes capital gains is potentially problematic. That is because trading in the associated assets is typically concentrated among people at the very top of the distribution. Within a top group, capital gains may therefore be directly reinvested into the purchase of the same assets. That is, they "net-out" for a hypothetical budget constraint of a top group. Hence, an increase in the top income share that is driven by capital gains is unlikely to provide additional saving of rich people that ends up as borrowing of other agents, as in Kumhof, Rancière, and Winant (2015).

Figure 3 illustrates this issue, showing the behavior of the top 1\% income share with and without capital gains for Spain and the United States around the 2007-09 financial crisis. In Spain, the top 1\% share that includes capital gains sharply rises between 2002 and 2006, whereas the move-

\footnotetext{
${ }^{10}$ Potential classic measurement error in the time series, in particular for the early years, would bias any of the following coefficient estimates towards zero. In this sense, my results can be seen as conservative lower-bound estimates. In fact, in Section 3.2, I show that the coefficient estimates are larger in absolute terms for a sample that is restricted to the post-WWII years.
} 
Top 1\% Share in Spain

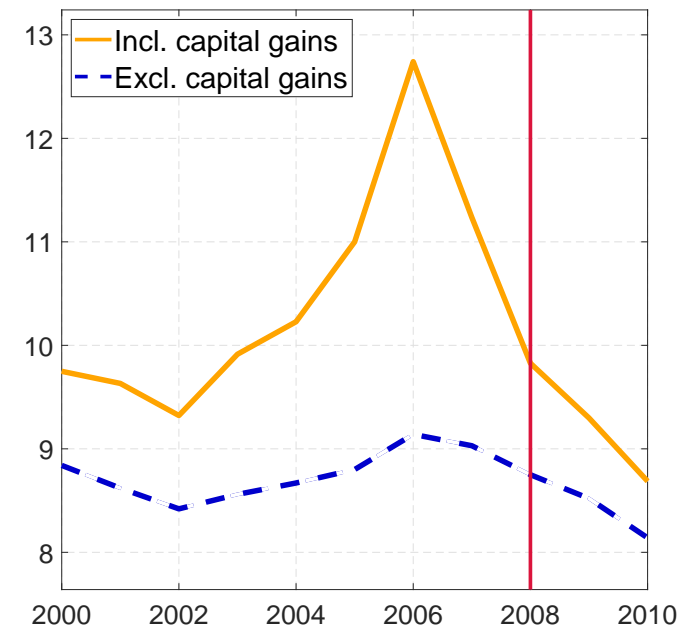

Top $1 \%$ Share in the United States

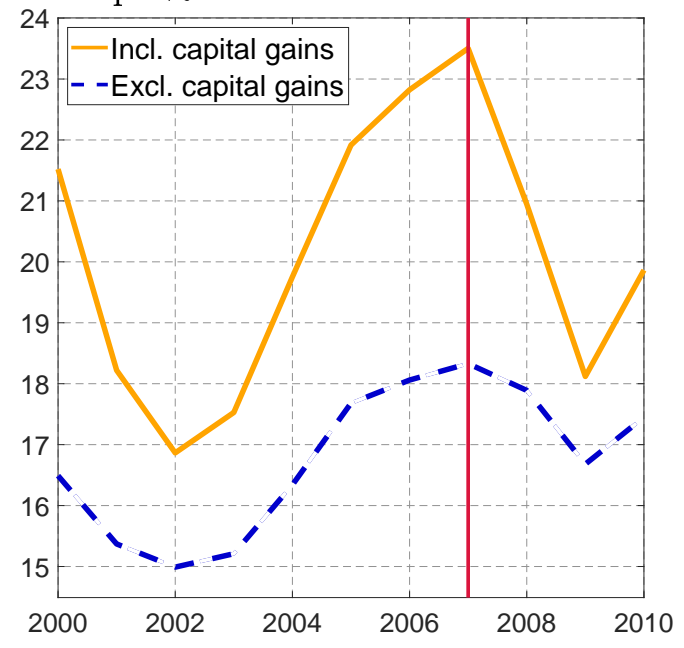

Figure 3: Top 1\% income share with and without capital gains. Red vertical lines indicate the start of a financial crisis based on Jordà et al. (2017). See Appendix E for details on the data sources.

ments are much smaller when capital gains are excluded from the income concept. For the United States, the top $1 \%$ share without capital gains rises substantially before 2007 . However, in comparison, the top $1 \%$ share that includes capital gains still increases around twice as much between 2002 and 2007.

Since asset price booms tend to precede financial crises (Borio and Lowe, 2002; Kiley, 2021), the inclusion of capital gains could also confound the relation between top income inequality and financial crises. Simply controlling for asset prices in the following regressions cannot resolve this issue. That is because taxes on capital gains vary across time and countries, often apply only to a subset of assets, and depend on the time when these assets were purchased. ${ }^{11}$ When taking the income share series "off-the-shelf" from the World Inequality Database, around half of the countries in the sample include capital gains. ${ }^{12}$ For consistency across countries and time periods, and to address the above issues, I therefore construct a new data set by adjusting the top income shares from the World Inequality Database to exclude capital gains. ${ }^{13}$ The full description of the data is left to the Data Appendix E, including descriptions on important tax law changes. ${ }^{14}$ Overall, the income share series are adjusted for 506 annual observations (top 1\% income share), and 383 (top $10 \%$ ), respectively.

\footnotetext{
${ }^{11}$ For example, an increase in the number of transactions and a higher turnover of assets may already result in higher top income shares. That is because capital gains often only apply to assets that have been purchased in the recent past.

${ }^{12}$ The top income share series largely overlap with the data by Roine and Waldenström (2015). An exception are the years 1990-1992 for Finland, which I add. The following results remain much the same without these additional data.

${ }^{13}$ For a few countries, it is not possible to separate out capital gains from the tax income data. For instance, capital gains may be reported together with other types of income. However, for the countries where that is the case, capital gains make up only a small fraction of overall income and are unlikely to introduce a bias (see Appendix E for details).

${ }^{14}$ I am grateful to many researchers around the world who have shared their data with me and who have helped me put this data set together.
} 

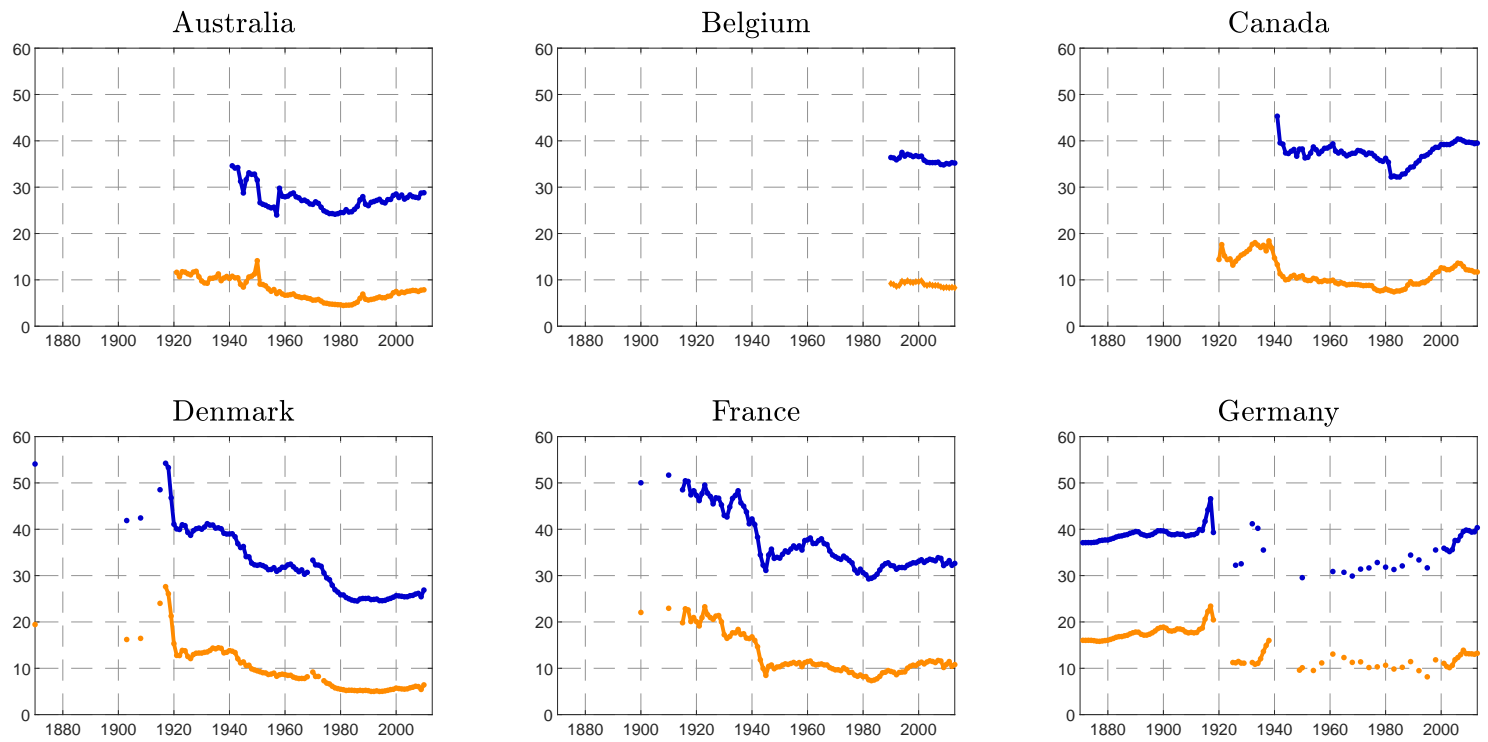

Finland
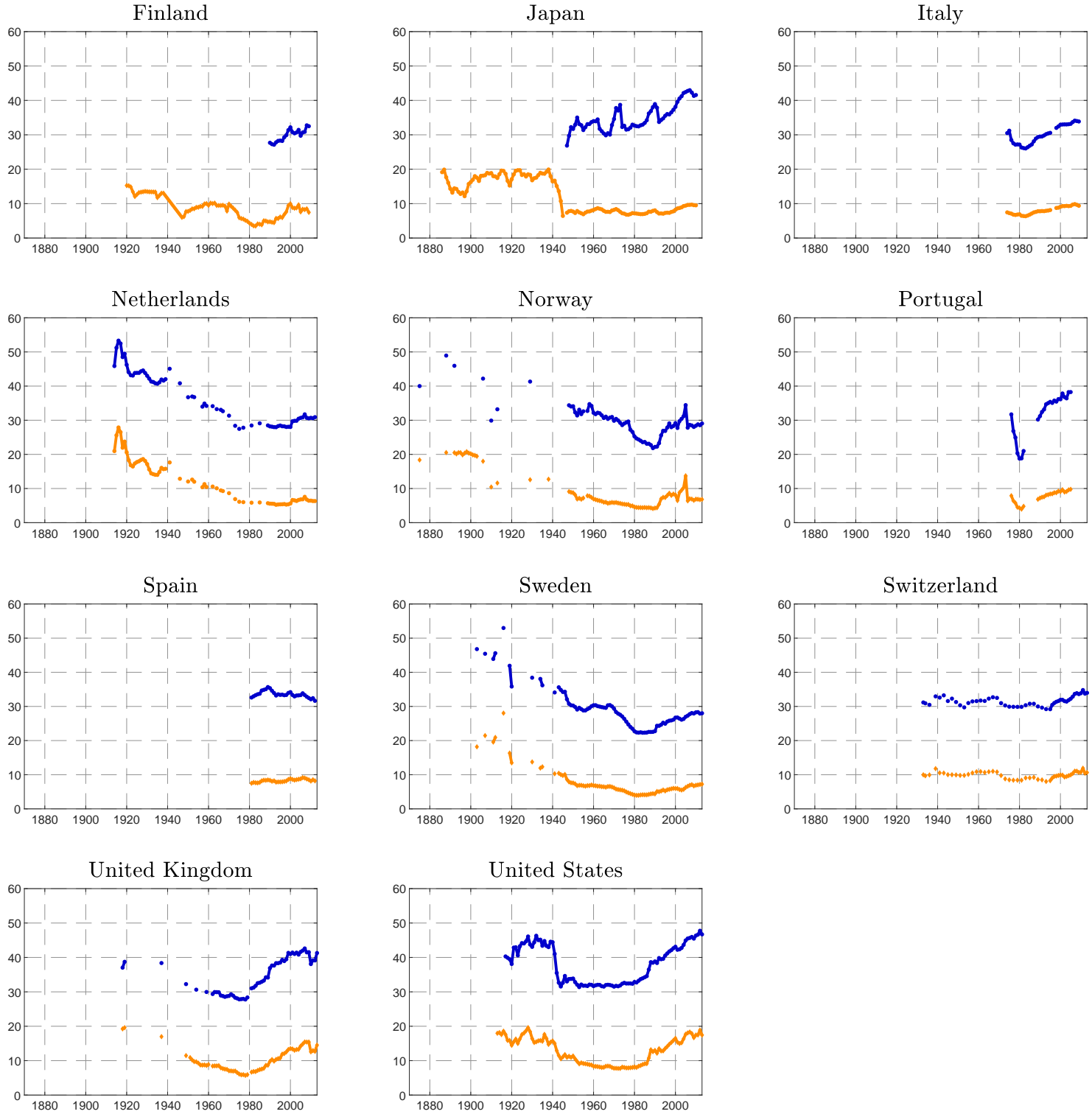

Figure 4: Income Shares of the Top 1\% (bottom lines) and the Top 10\% (upper lines). 
Figure 4 displays the resulting income share series for each country. I focus on the top $1 \%$ and the top $10 \%$ income shares since these series have the widest coverage. Noticeably, the inequality data are available for fewer years than the macrofinancial data. Moreover, some of the time series are interrupted, though the following results are robust to interpolating data over shorter gaps. Among other interesting dynamics, the subfigure for the United States shows the recent muchdiscussed rise of income inequality since the beginning of the 1980s.

\section{Predicting Financial Crises}

Figure 5 shows the typical behavior of the key variables of interest around financial crises. The annual percentage changes of real credit and the annual changes of the top income shares increase in the years leading up to a crisis and collapse once a financial crisis breaks out. In contrast, the various measures of annual productivity growth slow down slightly during the buildup phase and strongly decline around the outbreak of a crisis. Next, I use various statistical models to test whether top income inequality and productivity contain information to predict crises-above and beyond what is embedded in credit and other macrofinancial factors. In particular, consider the probabilistic model with the log-odds ratio

$$
\log \left(\frac{P\left[F C_{k, t}=1 \mid \cdot\right]}{P\left[F C_{k, t}=0 \mid \cdot\right]}\right)=\alpha_{k}+\beta_{1} \Delta_{h} Z_{k, t-1}+\beta_{2} \Delta_{h} X_{k, t-1}+u_{k, t}
$$

where $F C_{k, t}$ is equal to one if a financial crisis breaks out at time $t$ in country $k$ and zero otherwise, following the financial crises dates in Jordà et al. (2017). The log-odds ratio of $F C_{k, t}$ is assumed to be a function of a country-specific constant $\alpha_{k}$, the change of variable $Z$ from period $t-1-h$ to $t-1$ denoted by $\Delta_{h} Z_{k, t-1}$, and the change of a vector of controls $X$ from $t-1-h$ to $t-1$ defined similarly. In what follows, I normalize $X$ and $Z$ by their standard deviation to allow for a convenient interpretation of the marginal effects (for each respective sample). Figure 5 suggests that the medium-run movements within the five years prior to a crisis may be helpful to predict a financial crisis in the year ahead. I therefore set $h$ equal to 4 but the following results are robust to choosing $h=3$ or $h=5$ instead. Due to the differences in the availability of data, I first obtain evidence on the predictive power of income inequality and productivity separately, before considering their influence in joint regressions. Subsequently, I test whether the trend or cycle components explain the predictive relations in the data.

\subsection{Income Inequality}

Table 1 shows the estimation results for various versions of regression (1), for which the income share of the top $1 \%$ or the top $10 \%$ take the place of variable $Z$. To ease comparison, I restrict the sample for all estimations to be the same even though the data availability differs across variables. The first three columns evaluate the predictive power of credit and income inequality individually, whereas the last three columns consider them jointly. 


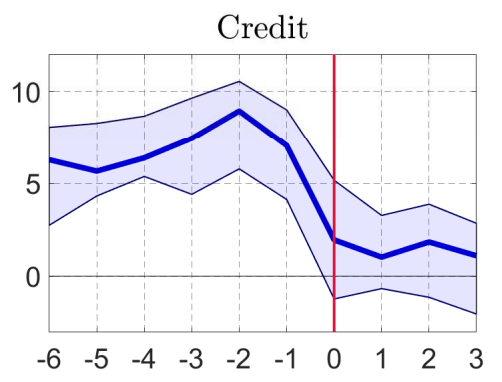

TFP

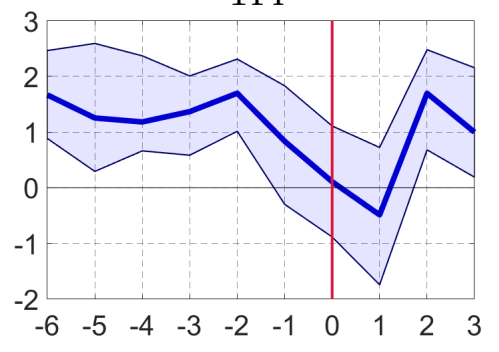

Income Share Top 1\%

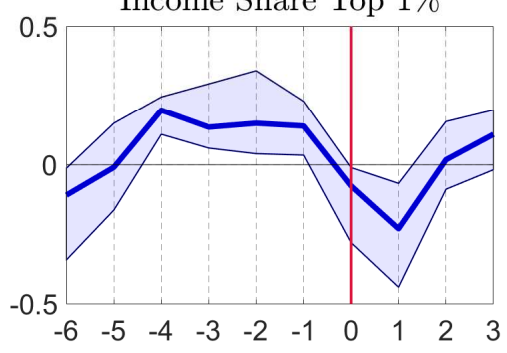

Util.-adj. TFP

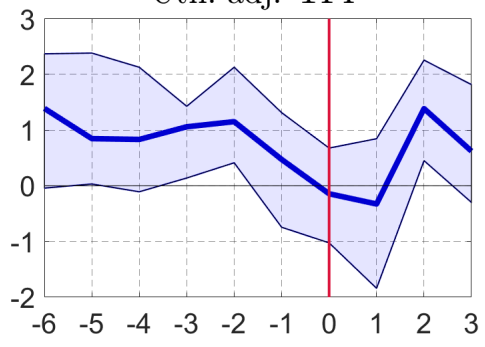

Income Share Top $10 \%$

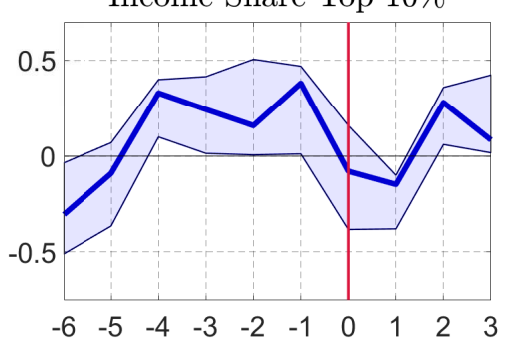

Labor Productivity

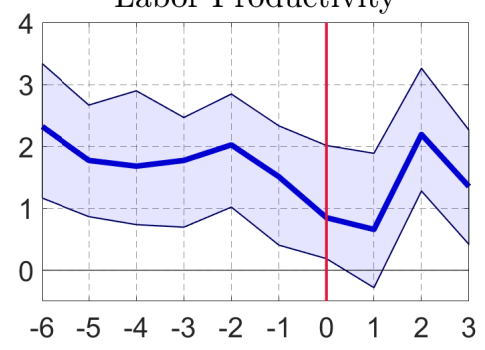

Figure 5: Annual (Percentage) Changes around Financial Crises. Median, $33^{\text {rd }}$, and $66^{\text {th }}$ percentiles.

The estimation results in the first column confirm a well-known finding in the literature: Aggregate measures of credit are statistically strong early-warning indicators for financial crises (Schularick and Taylor, 2012). In addition, columns 2-6 show that changes in top income shares are also statistically powerful predictors of crises. In fact, based on a commonly used early-warning performance measure for binary variables, the top $1 \%$ income share even slightly outperforms credit in predicting crises (see differences in AUROC between columns 1 and 2). ${ }^{15}$

Columns 4 and 5 show that the predictive power of the top income shares is preserved, though slightly smaller in magnitude, when credit is added into the regressions. These results can be explained by the fact that, holding credit constant, an increase in income inequality may result in higher debt-to-income ratios of poorer households and therefore an increase in their default risk. The estimated coefficients also imply economically important effects. For example, a onestandard-deviation increase of the top $1 \%$ income share within a four-year window at its mean implies an increase of around 2 percentage points in the probability that a crisis will occur within the next year (based on the estimation results in column 2). ${ }^{16}$ These effects can be considered substantial, given that the average frequency of crises is around $4 \%$ in the full sample.

Column 6 shows that the statistically significant relationship between financial crises and the top income shares is mainly driven by changes of the top $1 \%$ income share but not by changes in the top 2 to $10 \%$. That is because the coefficient on the latter is not statistically different from zero at the $90 \%$ confidence level, whereas the one on the former remains significant at the $99 \%$ level when

\footnotetext{
${ }^{15}$ AUROC stands for area under the receiver operating characteristic curve. The receiver operating characteristic curve plots true positive rates (specificity) against false positive rates (1-sensitivity) for a range of thresholds. The AUROC has the advantage that it is independent of a threshold choice. The curves that are based on the estimation results in columns 1 and 2 are plotted in Appendix Figure B.1.

${ }^{16}$ The standard-deviation of the top $1 \%$ share is $4.2 \%$, so a sizable fraction of aggregate output.
} 


\begin{tabular}{|c|c|c|c|c|c|c|}
\hline & $(1)$ & $(2)$ & (3) & (4) & (5) & (6) \\
\hline$\Delta_{4} \log (\text { Credit })_{\mathrm{t}-1}$ & $\begin{array}{c}0.811^{* *} \\
(0.342) \\
{[0.019]}\end{array}$ & & & $\begin{array}{c}0.874^{* *} \\
(0.375) \\
{[0.014]}\end{array}$ & $\begin{array}{c}0.740^{* *} \\
(0.355) \\
{[0.016]}\end{array}$ & $\begin{array}{c}0.874^{* *} \\
(0.392) \\
{[0.014]}\end{array}$ \\
\hline$\Delta_{4}$ Income Share $1 \%_{t-1}$ & & $\begin{array}{l}0.886^{* * *} \\
(0.258) \\
{[0.020]}\end{array}$ & & $\begin{array}{l}0.919 * * * \\
(0.279) \\
{[0.015]}\end{array}$ & & $\begin{array}{l}0.918^{* * *} \\
(0.272) \\
{[0.015]}\end{array}$ \\
\hline$\Delta_{4}$ Income Share $10 \%_{t-1}$ & & & $\begin{array}{l}0.649^{* * *} \\
(0.220) \\
{[0.017]}\end{array}$ & & $\begin{array}{l}0.611^{* *} \\
(0.294) \\
{[0.013]}\end{array}$ & $\begin{array}{c}0.002 \\
(0.219) \\
{[0.000]}\end{array}$ \\
\hline $\begin{array}{l}\text { Number of crises } \\
\text { Observations } \\
\text { Countries } \\
\text { Country FE } \\
\quad p \text {-value } \\
\text { Pseudo }{ }^{2} \\
\text { AUROC }\end{array}$ & $\begin{array}{c}26 \\
701 \\
14 \\
\checkmark \\
0.598 \\
0.091 \\
0.764^{* * *} \\
(0.050)\end{array}$ & $\begin{array}{c}26 \\
701 \\
14 \\
\checkmark \\
0.903 \\
0.113 \\
0.777^{* * *} \\
(0.050)\end{array}$ & $\begin{array}{c}26 \\
701 \\
14 \\
\checkmark \\
0.890 \\
0.076 \\
0.741^{* * *} \\
(0.048)\end{array}$ & $\begin{array}{c}26 \\
701 \\
14 \\
\checkmark \\
0.739 \\
0.166 \\
0.831^{* * *} \\
(0.046)\end{array}$ & $\begin{array}{c}26 \\
701 \\
14 \\
\checkmark \\
0.870 \\
0.120 \\
0.813^{* * *} \\
(0.044)\end{array}$ & $\begin{array}{l}26 \\
701 \\
14 \\
\checkmark \\
0.751 \\
0.166 \\
0.832^{* * *} \\
(0.046)\end{array}$ \\
\hline
\end{tabular}

Table 1: Predicting Financial Crises - Income Inequality. Results from logit regressions (1) with binary financial crisis indicator as dependent variable. The estimations cover the years 1888-2013. Notation: Robust standard errors in parentheses, marginal effects at mean in square brackets, the p-value refers to a test on the joint significance of the country-fixed effects, ${ }^{* * *} p<0.01,{ }^{* *} p<0.05,{ }^{*} p<0.1$.

both are included in a regression together with credit. Hence, capturing the income of earners at the very top of the income distribution is particularly important within the context of this paper.

Robustness. The mentioned results hold up to a range of robustness checks. For these checks, I only use the top $1 \%$ income share for brevity given the findings from column 6 in Table 1 . First of all, I test whether the identified relationship might in fact be picking up the influence of another indicator. In Table 2, I control for a large set of macro-financial factors simultaneously. The initial set includes the four-year changes of short- and long-term interest rates, the consumer price index, the ratios of investment, current account, public debt to GDP, and the same aggregate credit series as in Table 1. In column 2, I also control for changes in domestic and global real GDP to proxy for worldwide trends. ${ }^{17}$ To account for changes in asset valuations, I further include real stock and house prices in column 3-slightly reducing the sample size. Overall, the results remain largely unchanged. Hence, even when controlling for a wide range of other macro-financial fac-

\footnotetext{
${ }^{17}$ Global GDP is defined as the sum of real GDP across all countries in the sample.
} 


\begin{tabular}{lccc}
\hline & $(1)$ & $(2)$ & $(3)$ \\
\hline & & & \\
$\Delta_{4}$ Income Share $\%_{\mathrm{t}-1}$ & $0.707^{* * *}$ & $0.754^{* * *}$ & $0.826^{* * *}$ \\
& $(0.204)$ & $(0.205)$ & $(0.224)$ \\
& {$[0.011]$} & {$[0.011]$} & {$[0.008]$} \\
& & & \\
\hline & & & \\
Set of controls & $\checkmark$ & $\checkmark$ & $\checkmark$ \\
GDP \& Global GDP & & $\checkmark$ & $\checkmark$ \\
Stock \& House Prices & & & $\checkmark$ \\
& & & \\
\hline & & & \\
Number of crises & 31 & 31 & 29 \\
Observations & 813 & 813 & 769 \\
Countries & 15 & 15 & 15 \\
Country FE & $\checkmark$ & $\checkmark$ & $\checkmark$ \\
$\quad$ p-value & 0.755 & 0.818 & 0.313 \\
Pseudo R & & & \\
AUROC & 0.176 & 0.191 & 0.255 \\
& $0.821^{* * *}$ & $0.827^{* * *}$ & $0.868^{* * *}$ \\
& $(0.042)$ & $(0.039)$ & $(0.031)$ \\
\hline \hline
\end{tabular}

Table 2: Predicting Financial Crises - Additional Controls. Results from logit regressions (1) with binary financial crisis indicator as dependent variable. The "set of controls" in column (1) includes fouryear changes of short- and long-term interest rates, the consumer price index, the ratios of investment, current account, public debt to GDP, and aggregate credit. Notation: Robust standard errors in parentheses, marginal effects at mean in square brackets, the p-value refers to a test on the joint significance of the country-fixed effects, ${ }^{* * *} p<0.01,{ }^{* *} p<0.05,{ }^{*} p<0.1$.

tors, changes in the top $1 \%$ income share still have predictive power for crises. ${ }^{18,19}$

The remaining robustness exercises are shown in Appendix B.1. Starting from the regression in column 4 of Table 1, Appendix Table B.1 considers several deviations from this baseline. First, splitting the sample into pre- and post-WWII, the statistical relationship becomes insignificant at conventional confidence levels for the pre-WWII sample due to the few observations left, whereas the conclusions based on the post-WWII sample compared to the baseline remain much the same. Second, the potential effect of income inequality on financial crises is often mentioned with respect to the Great Depression and the Great Recession (Galbraith, 1997, Rajan, 2010, Kumhof et al., 2015). When excluding these two episodes from the sample, the relationship is still significant at the $95 \%$ confidence level, though smaller in magnitude. Third, I check whether the predictive power of income inequality is unique to financial recessions or holds more generally for nonfinancial re-

\footnotetext{
${ }^{18}$ Based on data from the World Inequality Database, I also test for the predictive power of the national wealth-toincome ratio (see Appendix Table B.3). The wealth-to-income ratio is a powerful predictor of crises as well. However, when controlling for changes in real stock and house prices, key drivers of wealth, the coefficient becomes indistinguishable from zero. Thus, the predictive power mainly arises from changes in asset prices.

${ }^{19} \mathrm{~A}$ similar test for wealth inequality is unfortunately not feasible at this stage due to data limitations (see also Saez and Zucman, 2016). For example, the World Inequality Database contains wealth inequality data for only three out of the 17 countries in this paper. Even after adding observations for seven additional countries based on the data by Roine and Waldenström (2015), I do not find that wealth inequality is a statistically significant predictor of crises.
} 
cessions as well (using the recession definitions from Jordà et al., 2013). I find that the relation between income inequality and nonfinancial recessions is in fact negative. ${ }^{20}$

Next, I check whether the findings depend on the specific crises dates by Jordà et al. (2017), since Bordo and Meissner (2016) document substantial differences across data sets. In Appendix Table B.2, I repeat the estimation of Table 1 using various alternative financial crises dates. In particular, I consider the banking crises dates by Reinhart and Rogoff (2009b) (available years: 1870-2010), the systemic banking crises dates by Laeven and Valencia (2013) (1970-2011), the financial crises dates by Bordo et al. (2001) (1880-1997), and the financial distress measure by Romer and Romer (2017) (1967-2012). ${ }^{21}$ Strikingly, using these various financial crises dates, the results are largely unchanged. Last, in unreported robustness exercises, I further test and confirm that the results persist when using smaller or wider windows for $h$ in regression (1) ( $h=3$ or $h=5$ ), linearly interpolating over gaps of up to three years in the inequality measures, or when considering outof-sample forecasts based on rolling regressions using only past data.

\subsection{Productivity}

This section repeats the estimation of various versions of regression (1), but instead of the top income shares taking the place of variable $Z$, I now consider different measures of productivity. In particular, I focus on the predictive power of utilization-adjusted TFP and labor productivity as they are defined in Section 2.2 and Appendix A.2. Table 3 shows the estimation results.

The main findings are in columns $2-5$. Both productivity measures are strong predictors of financial crises-even (more so) if credit is included. If countries experience below-average productivity growth, the likelihood of a financial crisis increases. However, the productivity measures do not outperform credit as predictors based on the considered early-warning performance measure (comparing again the differences in the AUROC measure in columns 1, 2, and 3). ${ }^{22}$ However, this changes when considering the post-WWII sample only, for which both productivity measures outperform credit as predictor variables (see Appendix Table B.4). ${ }^{23}$ The estimated effects of productivity are sizable: Based on the regression results in column 5, if labor productivity growth is one standard deviation below the country-specific mean, then the probability of a financial crisis occurring within the next year increases by around 1.3 percentage points.

\footnotetext{
${ }^{20}$ In Data Appendix E, I document various tax law changes that may induce variation in the top income shares, as, for example, due to changes in the definition of the tax unit (e.g., United Kingdom 1989-1990) or because of changes in the tax code (e.g., Norway around 2006). I find that none of them drives the results in this paper when excluding the years around them.

${ }^{21}$ The first three are annual binary indicators denoting the start of a financial crisis. In contrast, Romer and Romer (2017) develop a semi-annual financial distress measure that ranges from 0 (no distress) to 15 (extreme distress) and can be non-zero for several years in a row. To reconcile this measure with the previous analysis, I convert it into an annual binary indicator that equals one if the financial distress measure is larger or equal to one within one year, but not in the previous year, capturing the start of a crisis.

${ }^{22}$ The associated curves for the results in columns 1 and 3 are plotted in Appendix Figure B.2.

${ }^{23} \mathrm{~A}$ model with only country-fixed effects has an AUROC of 0.601 . Compared with this model, the additional improvement from adding any of the productivity measures is therefore small (see Table 3). However, this changes for the post-WWII sample, for which the AUROC improves by around 0.075 (utilization-adjusted TFP) and 0.1 (LP), when
} 


\begin{tabular}{lccccc}
\hline & $(1)$ & $(2)$ & $(3)$ & $(4)$ & $(5)$ \\
\hline & & & & & \\
$\Delta_{4} \log (\text { Credit })_{\mathrm{t}-1}$ & $0.458^{* * *}$ & & & $0.537^{* * *}$ & $0.597^{* * *}$ \\
& $(0.126)$ & & & $(0.142)$ & $(0.147)$ \\
& {$[0.013]$} & & & {$[0.014]$} & {$[0.015]$} \\
& & & & & \\
$\Delta_{4} \log (\mathrm{TFP})_{\mathrm{t}-1}^{\text {util-adj. }}$ & & $-0.269^{* *}$ & & $-0.407^{* * *}$ & \\
& & $(0.129)$ & & $(0.132)$ & \\
& & {$[-0.008]$} & & {$[-0.011]$} & \\
$\Delta_{4} \log (\mathrm{LP})_{\mathrm{t}-1}$ & & & & & $-0.512^{* * *}$ \\
& & & $-0.303^{* * *}$ & & $(0.124)$ \\
& & & $(0.115)$ & & {$[-0.013]$} \\
& & & {$[-0.009]$} & & \\
Number of crises & 53 & 53 & 53 & 53 & 53 \\
Observations & 1552 & 1552 & 1552 & 1552 & 1552 \\
Countries & 17 & 17 & 17 & 17 & 17 \\
Country FE & $\checkmark$ & $\checkmark$ & $\checkmark$ & $\checkmark$ & $\checkmark$ \\
$\quad$-value & 0.963 & 0.983 & 0.981 & 0.946 & 0.943 \\
Pseudo R & & & & & 0.066 \\
AUROC & 0.044 & 0.024 & 0.025 & 0.058 & $0.724^{* * * *}$ \\
& $0.695^{* * *}$ & $0.626^{* * *}$ & $0.636^{* * *}$ & $0.711^{* * *}$ & \\
& $(0.035)$ & $(0.040)$ & $(0.038)$ & $(0.035)$ & $(0.032)$ \\
\hline \hline
\end{tabular}

Table 3: Predicting Financial Crises - Productivity. Results from logit regressions (1) with binary financial crisis indicator as dependent variable. The estimations cover the years 1895-2013. Notation: Robust standard errors in parentheses, marginal effects at mean in square brackets, the p-value refers to a test on the joint significance of the country-fixed effects, ${ }^{* * *} p<0.01,{ }^{* *} p<0.05,{ }^{*} p<0.1$.

Robustness. As before, I take the results from Table 3 as benchmarks. I start from the ones reported in column 5, given the fact that labor productivity outperforms utilization-adjusted TFP in terms of the AUROC performance measure. I again check whether adding a range of other macroeconomic and financial variables may change the relationship between productivity and financial crises. In Table 4, I first include the same set of controls as in Table 2. Further, I add stock and house prices, and then the top $1 \%$ income share; both steps reduce the sample size. ${ }^{24}$ Again, the predictive power of labor productivity remains intact.

From the benchmark in column 5 of Table 3, I consider several further modifications that are shown in Appendix Table B.5. First, the statistically significant relationship between productivity and financial crises is mainly a post-WWII phenomenon-it does not hold for a pre-WWII sample. Hence, the years immediately after post-WWII-with strong growth and few crises-seem to be important for the identified relation. Second, labor productivity does not have predictive power for nonfinancial recessions. Third, the input factor part within a Cobb-Douglas production

adding changes in productivity growth to a model with only country-fixed effects (see Appendix Table B.4).

${ }^{24}$ Due to the strong correlation between labor productivity and domestic as well as global GDP, I do not include these variables as controls. 


\begin{tabular}{lccc}
\hline & $(1)$ & $(2)$ & $(3)$ \\
\hline$\Delta_{4} \log (\mathrm{LP})_{\mathrm{t}-1}$ & & & \\
& $-0.553^{* * *}$ & $-0.550^{* *}$ & $-0.793^{* *}$ \\
& $(0.134)$ & $(0.216)$ & $(0.355)$ \\
& {$[-0.012]$} & {$[-0.010]$} & {$[-0.008]$} \\
& & & \\
\hline & & & \\
Set of controls & $\checkmark$ & $\checkmark$ & $\checkmark$ \\
Stock \& House Prices & & $\checkmark$ & $\checkmark$ \\
Income Share 1\% & & & $\checkmark$ \\
& & & \\
\hline & & & \\
Number of crises & 53 & 41 & 29 \\
Observations & 1387 & 1145 & 769 \\
Countries & 16 & 16 & 15 \\
Country FE & $\checkmark$ & $\checkmark$ & $\checkmark$ \\
$\quad$-value & 0.849 & 0.782 & 0.132 \\
Pseudo R & & & \\
AUROC & 0.115 & 0.141 & 0.249 \\
& $0.756^{* * *}$ & $0.778^{* * *}$ & $0.857^{* * *}$ \\
& $(0.033)$ & $(0.036)$ & $(0.036)$ \\
\hline \hline
\end{tabular}

Table 4: Predicting Financial Crises - Additional Controls. Results from logit regressions (1) with binary financial crisis indicator as dependent variable. The "set of controls" in column (1) includes fouryear changes of short- and long-term interest rates, the consumer price index, the ratios of investment, current account, public debt to GDP, and aggregate credit. Notation: Robust standard errors in parentheses, marginal effects at mean in square brackets, the p-value refers to a test on the joint significance of the country-fixed effects, ${ }^{* * *} p<0.01,{ }^{* *} p<0.05,{ }^{*} p<0.1$.

function, given by $Y_{t} / A_{t}=K_{t}^{\alpha} H_{t}^{1-\alpha}$ following the notation in Section 2.2, does not have the same predictive power as productivity.

The findings also remain much the same when using the alternative financial crises dates by Reinhart and Rogoff (2009b), Laeven and Valencia (2013), Bordo et al. (2001), or Romer and Romer (2017) (see Appendix Table B.6). In unreported robustness exercises, I further test and confirm that the results remain largely unchanged when using smaller or wider windows for $h$ in regression (1) $(h=3$ or $h=5)$ or when considering out-of-sample forecasts based on rolling regressions using only past data. Last, I conduct a horse race between credit, the top 1\% income share, and labor productivity (see Appendix Table B.7) ${ }^{25}$ While the estimated coefficients of the three variables are similar as in Tables 1-4, a comparison of the AUROC statistics shows that the top 1\% income share provides the strongest predictive power.

\section{Trend vs. Cycle}

The previous section has shown that changes in top income shares and productivity growth are robust early-warning indicators of crises. Should policymakers therefore be worried anytime top

\footnotetext{
${ }^{25}$ For this comparison, I exclude country-fixed effects to increase the number of observations.
} 
income shares quickly rise or productivity growth temporarily drops? Or does financial crisis risk rather build up slowly over many years of persistently rising income inequality or low productivity growth? To shed light on these differences, I test whether the predictive relations are due to the cycle or the trend component within each variable in this section.

To this end, I use the filter proposed by Hamilton (2018) which addresses several drawbacks of the Hodrick-Prescott filter. Hamilton's method estimates a trend at time $t$ of some variable $y_{t}$ in (log-)levels based on an OLS regression with four lags,

$$
\hat{y}_{t}=\hat{\alpha}+\hat{\beta}_{1} y_{t-k}+\hat{\beta}_{2} y_{t-k-1}+\hat{\beta}_{3} y_{t-k-2}+\hat{\beta}_{4} y_{t-k-3}
$$

For the macro-financial data by Jordà et al. (2017), Hamilton (2018) suggests to consider $k=5$. To allow for country-specific dynamics and decompositions in real time, I estimate rolling regressions for each variable and country using only data available up to some time period $t$.

The results for labor productivity, util.-adj. TFP, and the top 1\% income share are shown in Table 5. For each variable, I show the estimation results based on regression (1) (without additional regressors) and its decomposition into trend and cycle (each measured by changes over four years). Columns 1-4 show that the negative relation between productivity and financial crises is due to the trend component. The cyclical part is statistically insignificant for both labor productivity and util.-adj. TFP. For the top 1\% income share, both components have predictive power. A onestandard-deviation increase in the cyclical part within a four-year window at its mean implies an increase of around 2.1 percentage points in the probability that a crisis will occur within the next year, whereas the equivalent exercise raises the risk of a crisis by around 1.1 percentage points for the trend component. Hence, these results show that longer run trends in income inequality and productivity growth have sizeable predictive power for the risk of a financial crisis in the near term.

I repeat the exercise in Table 5 for other variables that have been shown to be strong crisis predictors: stock prices, house prices, credit, and the current account (e.g., Schularick and Taylor, 2012; Kiley, 2021). ${ }^{26}$ The results are shown in Appendix Table C.1. For stock prices and the current account, the predictive relations are solely explained by the cyclical part, confirming the intuition that temporary changes in those relatively fast-moving indicators typically precede crises. For house prices and credit, both high cyclical and trend growth raise the likelihood of a crisis. While the cyclical part for both variables is quantitatively more important, a sole focus on deviations of house prices and credit from their trend growth may therefore not capture the full extent of their contribution to the risk of financial crises.

\footnotetext{
${ }^{26}$ More specifically, I consider real stock prices, real house prices, and real credit (all in logs), as well as the current account to GDP ratio.
} 


\begin{tabular}{lcccccc}
\hline & \multicolumn{2}{c}{ Labor Productivity } & \multicolumn{2}{c}{ Util.-adj. TFP } & \multicolumn{2}{c}{ Top1\% Share } \\
& $(1)$ & $(2)$ & $(3)$ & $(4)$ & $(5)$ & $(6)$ \\
\hline & & & & & & \\
$\Delta_{4}(.)_{\mathrm{t}-1}$ & $-0.371^{* * *}$ & & $-0.300^{* *}$ & & $0.644^{* * *}$ & \\
& $(0.113)$ & & $(0.120)$ & & $(0.222)$ & \\
& {$[-0.011]$} & & {$[-0.008]$} & & {$[0.017]$} & \\
& & & & & & $0.819^{* * *}$ \\
Cycle & & -0.180 & & -0.157 & & $(0.293)$ \\
& & $(0.129)$ & & $(0.142)$ & & {$[0.021]$} \\
& & {$[-0.005]$} & & {$[-0.004]$} & & \\
Trend & & $-0.577^{* * *}$ & & $-0.545^{* * *}$ & & $0.424^{* *}$ \\
& & $(0.168)$ & & $(0.174)$ & & $(0.211)$ \\
& & {$[-0.016]$} & & {$[-0.014]$} & & {$[0.011]$} \\
& & & & & & \\
& & & & & & \\
Number of crises & 49 & 49 & 35 & 35 & 20 & 20 \\
Observations & 1383 & 1383 & 1088 & 1088 & 518 & 518 \\
Countries & 17 & 17 & 17 & 17 & 14 & 14 \\
Country FE & $\checkmark$ & $\checkmark$ & $\checkmark$ & $\checkmark$ & $\checkmark$ & $\checkmark$ \\
$p$-value & 0.946 & 0.943 & 0.970 & 0.971 & 0.788 & 0.774 \\
Pseudo R ${ }^{2}$ & 0.035 & 0.042 & 0.037 & 0.046 & 0.086 & 0.089 \\
AUROC & $0.665^{* * *}$ & $0.682^{* * *}$ & $0.669^{* * *}$ & $0.685^{* * *}$ & $0.737^{* * *}$ & $0.742^{* * *}$ \\
& $(0.037)$ & $(0.037)$ & $(0.044)$ & $(0.041)$ & $(0.059)$ & $(0.058)$ \\
& & & & & & \\
\hline \hline
\end{tabular}

Table 5: Predicting Financial Crises - Trend vs. Cycle. Results from logit regressions with binary financial crisis indicator as dependent variable. Linear regression $\hat{y}_{t}=\hat{\alpha}+\hat{\beta}_{1} y_{t-5}+\hat{\beta}_{2} y_{t-6}+\hat{\beta}_{3} y_{t-7}+$ $\hat{\beta}_{4} y_{t-8}$ used to predict trend at time $t$ following Hamilton (2018). Notation: Robust standard errors in parentheses, marginal effects at mean in square brackets, the p-value refers to a test on the joint significance of the country-fixed effects, ${ }^{* * *} p<0.01,{ }^{* *} p<0.05,{ }^{*} p<0.1$.

\section{Severity of Recessions}

The results thus far show that both movements in top income inequality and productivity growth have predictive power with respect to the likelihood of financial crises. Next, I study whether these variables are also informative about the severity of recessions. Since there are relatively few financial recessions in the data, I consider all types of recessions jointly.

The response of output varies substantially across countries and periods during recessions. Some countries experience prolonged spells of depressed output, while others recover relatively quickly. Part of this variation may be due to pre-recession trends in income inequality and productivity. To get a first sense on whether this might be the case, I distinguish between the path of output during recessions following either high or low growth in top income inequality or productivity. In particular, I consider the average percentage change in real GDP after the start of a recession that was preceded by changes in the top $1 \%$ income share or labor productivity growth more than one-standard-deviation above (or below) average over the three preceding years. 

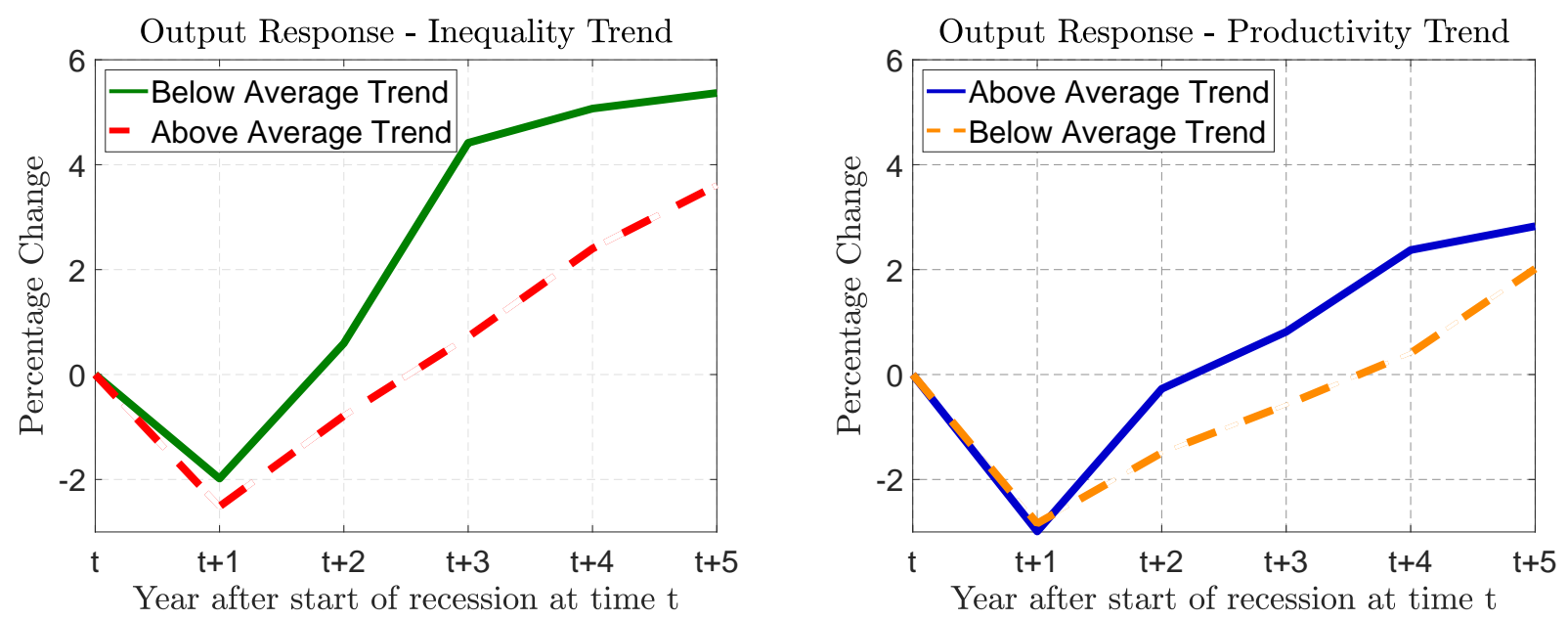

Figure 6: Behavior of Output during Recessions. Average percentage change in real GDP after the start of a recession at time $t$, differentiated by pre-recession changes in the top $1 \%$ income share and labor productivity (more than one standard deviation above or below average growth over the three preceding years).

The findings of this exercise are shown in Figure 6. If recessions are preceded by changes in top income inequality substantially above average, then output declines more strongly compared with recessions that are characterized by changes in top income inequality much below average. Similarly, output also falls more strongly during recessions that are preceded by unusually low productivity growth, compared with the ones associated with substantially above average productivity growth. Hence, pre-recession trends in top income inequality and productivity seem to affect the severity of recessions.

However, other factors might be correlated with these pre-recession trends that would in fact determine the variation shown in Figure 6. In a next step, I therefore control for a range of other variables and also test for the statistical significance of the various estimates. To this end, I use the local projection approach by Jordà (2005). Denote (log) real GDP in country $k$ at time $t$ by $y_{k, t}$ and consider the set of regressions

$$
y_{k, t+h}-y_{k, t}=\beta^{h}+\gamma^{h} \Delta_{3} Z_{k, t}+\Gamma_{1}^{h} X_{k, t}+\Gamma_{2}^{h} X_{k, t-1}+u_{k, t}^{h} \quad \text { for } h=1, \ldots, 5,
$$

where the dependent variable gives the percentage change in output from time $t$ to $t+h$ and $X_{k, t}$ is a vector of controls. In $X_{k, t}, I$ include the annual percentage changes in real GDP, investment, and aggregate credit from $t-1$ to $t$, as well as inflation and the current account at time $t$. Since Romer and Romer (2018) find that monetary and fiscal space matters for the aftermath of crises, I also add nominal short- and long-term interest rates and the public debt-to-GDP ratio at time $t$.

The set of regressions are estimated only for periods $t$ that indicate the start of a recession as defined in Section 2.1. The coefficient $\beta^{h}$ therefore gives the average percentage change in output $h$ years after the start of a recession. The additional effect of the buildup period on the response of 

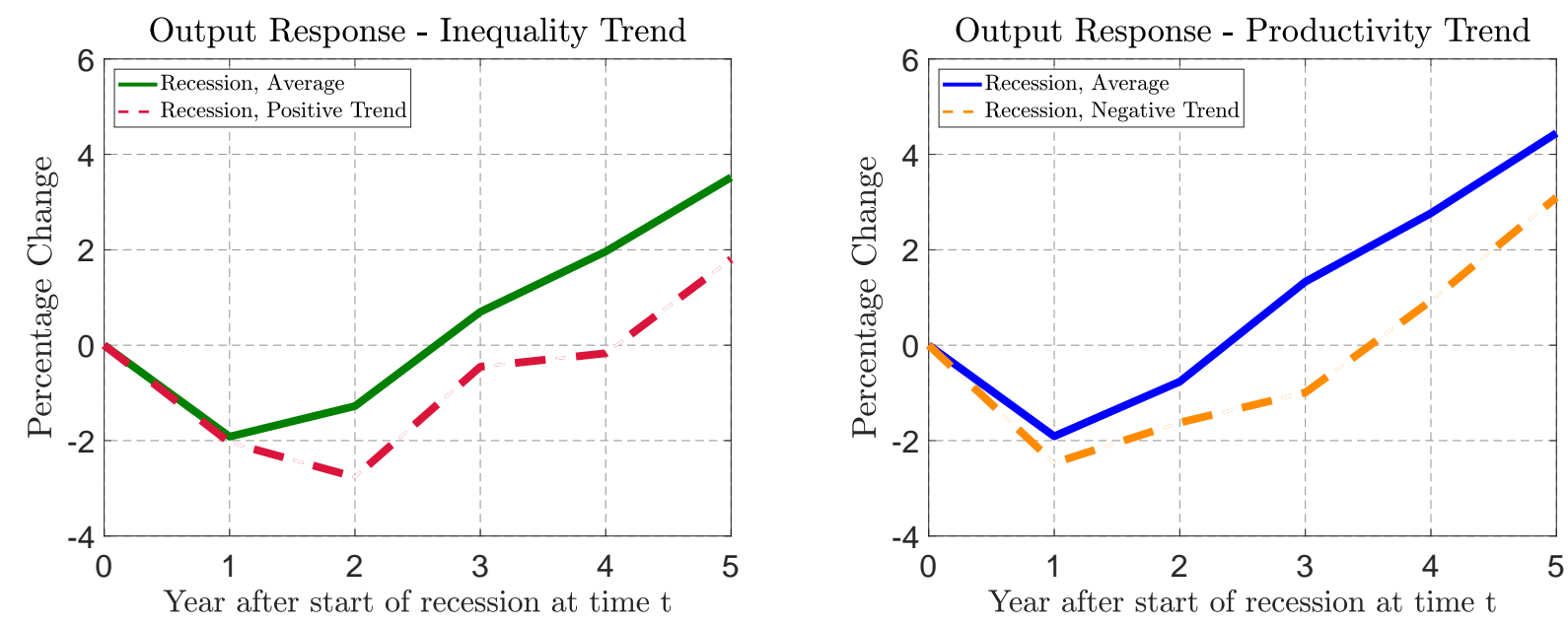

Figure 7: Behavior of Output during Recessions. Estimated percentage change in real GDP after start of a recession at time $t$, differentiated by positive pre-recession trends in top income inequality and negative pre-recession trends in productivity (1.5 standard deviation above or below mean).

output is captured by $\Delta_{3} Z_{k, t} \cdot{ }^{27}$ The variable $\Delta_{3} Z_{k, t}$ follows the definition in Section 3 and is again normalized to standard deviation one. The typical percentage change of output after the start of a recession that was also preceded by a one-standard-deviation change in $Z$ above its mean over the previous three years is then given by $\beta^{h}+\gamma^{h}$ at horizon $h$.

Due to the differences in the availability of data, I again obtain evidence for top income inequality and productivity separately. In particular, I consider changes in the top $1 \%$ income share and labor productivity growth which take the place of variable $Z$ in regressions (2). The estimation results are given in Appendix Tables D.1 and D.2. Figure 7 summarizes the findings graphically. The left graph shows the estimation results for which the top $1 \%$ income share takes the place of variable $Z$; the right graph for which $Z$ is given by (log) labor productivity.

Recessions that occur after excess increases in top income inequality or low productivity growth are associated with stronger declines in output. Tables D.1 and D.2 show that these differencesgiven by the coefficients $\hat{\gamma}^{h}$-are statistically significant at standard confidence levels, though not for every horizon $h$. Thus, the results show that changes in top income inequality and productivity growth are informative not only about the likelihood of financial crises but also the severity of recessions, even when controlling for a range of other macroeconomic and financial factors.

\section{Conclusion}

Rising top income inequality and low productivity growth are robust predictors of financial crises, and their slow-moving trend components explain these relations to a large extent. Moreover, if recessions are preceded by such developments, then output declines more strongly subsequently.

\footnotetext{
${ }^{27}$ Here, I choose three-year differences to avoid any overlap with previous business cycle peaks. However, I find that the following results are robust to considering four- or five-year windows for the change in $Z$.
} 
These are the findings based on a long-run historical data set of macrofinancial, productivity, and income inequality data for the vast majority of advanced economies. For the purpose of this paper, I have collected data on top income shares that exclude capital gains and thereby movements in asset prices. I hope that this data will be of use to other researchers in the future.

It is important to highlight that all my results represent predictive and not causal relations. Hence, it is a challenging but exciting task for future research to address the issue of causality, while also understanding the transmission channels in more depth. Nonetheless, the results suggest that "real-economy factors" - productivity growth and the distribution of income-are relevant determinants for macrofinancial stability, which may increase the fragility of economies, such as the United States prior to the 2007-09 financial crisis when productivity growth was slowing and income inequality rising (Paul and Pedtke, 2020).

My findings also have important implications for macrofinancial modeling. Theoretical models of financial crises should be able to match the described patterns in the data. While a few recent papers have attempted to replicate the fact that financial crises occur out of temporary creditintensive booms (e.g., Paul, 2020), the vast majority of the current generation of macrofinance models do not allow for slow-moving trend changes to affect financial stability. This is another important area for future research, since data-consistent models are needed to analyze the effectiveness of various macroprudential policies.

\section{References}

Alstadsæter, A., M. Jacob, W. Kopczuk, and K. Telle (2017). Accounting for business income in measuring top income shares. Integrated accrual approach using individual and firm data from Norway. NBER Working Paper 837.

Anundsen, A. K., K. Gerdrup, F. Hansen, and K. Kragh-Sørensen (2016). Bubbles and crises: The role of house prices and credit. Journal of Applied Econometrics 31(7), 1291-1311.

Baron, M. and W. Xiong (2017). Credit expansion and neglected crash risk. Quarterly Journal of Economics 132(2), 713-764.

Bergeaud, A., G. Cette, and R. Lecat (2016). Productivity trends in advanced countries between 1890 and 2012. Review of Income and Wealth 62(3), 420-444.

Bernanke, B., T. Geithner, and H. Paulson (2018). What we need to fight the next financial crisis. New York Times, September 7 .

Boissay, F., F. Collard, and F. Smets (2016). Booms and banking crises. Journal of Political Economy 124(2), 489-538.

Bordo, M., B. Eichengreen, D. Klingebiel, and M. S. Martinez-Peria (2001). Is the crisis problem growing more severe? Economic Policy 16, 52-82.

Bordo, M. and C. Meissner (2016). Fiscal and financial crises. Handbook of Macroeconomics 2, 355 - 412. 
Bordo, M. D. and C. M. Meissner (2012). Does inequality lead to a financial crisis? Journal of International Money and Finance 31(8), 2147-2161.

Borio, C. and P. Lowe (2002). Asset prices, financial and monetary stability: exploring the nexus. BIS Working Paper (114).

Brunnermeier, M. K. and Y. Sannikov (2014). A macroeconomic model with a financial sector. American Economic Review 104(2), 379-421.

Bry, G. and C. Boschan (1971). Cyclical analysis of time series: Selected procedures and computer programs. National Bureau of Economic Research, Inc.

Cairó, I. and J. Sim (2018). Income inequality, financial crisis and monetary policy. Finance and Economics Discussion Series, Federal Reserve Board of Governors (048).

Cairó, I. and J. Sim (2020). Market power, inequality, and financial instability. Finance and Economics Discussion Series, Federal Reserve Board of Governors 2020-057.

Cao, D. and J.-P. L'Huillier (2018). Technological revolutions and the three great slumps: A medium-run analysis. Journal of Monetary Economics 96, 93-108.

Comin, D. and M. Gertler (2006). Medium-term business cycles. American Economic Review 96(3), 523-551.

Davis, J. S., A. Mack, W. Phoa, and A. Vandenabeele (2016). Credit booms, banking crises, and the current account. Journal of International Money and Finance 60, 360 - 377.

Dell' Ariccia, G., D. Igan, L. Laeven, and H. Tong (2016). Credit booms and macrofinancial stability. Economic Policy, 299-357.

Demirgüç-Kunt, A. and E. Detragiache (1998). The determinants of banking crises in developing and developed countries. IMF Staff Papers 45(1).

Feenstra, R. C., R. Inklaar, and M. P. Timmer (2015). The next generation of the penn world table. American Economic Review 105(10), 3150-82.

Fernald, J. (2014). A quarterly, utilization-adjusted series on total factor productivity. Federal Reserve Bank of San Francisco - Working Paper Series.

Fernald, J. (2015). Productivity and potential output before, during, and after the Great Recession. NBER Macroeconomics Annual 29(1), 1-51.

Galbraith, J. K. (1997). The Great Crash of 1929. Mariner Books.

Gertler, M. and N. Kiyotaki (2010). Financial intermediation and credit policy in business cycle analysis. Handbook of Monetary Economics 3, 547-599.

Gorton, G. and G. Ordoñez (2020). Good booms, bad booms. Journal of the European Economic Association 18(2), 618-665.

Hamilton, J. (2018). Why you should never use the hodrick-prescott filter. Review of Economics and Statistics 100 .

He, Z. and A. Krishnamurthy (2019). A macroeconomic framework for quantifying systemic risk. American Economic Journal: Macroeconomics 11(4), 1-37. 
Herrera, H., G. Ordoñez, and C. Trebesch (2020). Political booms, financial crises. Journal of Political Economy 128(2), 507-543.

Imbs, J. M. (1999). Technology, growth and the business cycle. Journal of Monetary Economics 44(1), 65-80.

Jordà, O. (2005). Estimation and inference of impulse responses by local projections. American Economic Review 95(1), 161-182.

Jordà, O., M. Schularick, and A. Taylor (2013). When credit bites back. Journal of Money, Credit and Banking 45(s2), 3-28.

Jordà, O., M. Schularick, and A. Taylor (2017). Macrofinancial history and the new business cycle facts. NBER Macroeconomics Annual 2016, Volume 31.

Kaminsky, G. L. and C. M. Reinhart (1999). The twin crises: The causes of banking and balance-of-payments problems. American Economic Review 89(3), 473-500.

Kiley, M. (2021). What macroeconomic conditions lead financial crises. Journal of International Money and Finance 111(C).

Kindleberger, C. P. (1978). Manias, Panics, and Crashes: A History of Financial Crises. Basic Books, New York.

Kirschenmann, K., T. Malinen, and H. Nyberg (2016). The risk of financial crises: Is there a role for income inequality? Journal of International Money and Finance 68, 161 - 180.

Knoll, K., M. Schularick, and T. Steger (2017). No price like home: Global house prices, 1870-2012. American Economic Review 107(2), 331-53.

Krishnamurthy, A. and T. Muir (2017). How credit cycles across a financial crisis. NBER Working Papers (23580).

Kumhof, M., R. Rancière, and P. Winant (2015). Inequality, leverage, and crises. American Economic Review 105(3), 1217-45.

Laeven, L. and F. Valencia (2013). Systemic banking crises database. IMF Economic Review 61(2), 225-270.

Mendoza, E. G. and M. E. Terrones (2014). An anatomy of credit booms and their demise. In Capital Mobility and Monetary Policy, Volume 18 of Central Banking, Analysis, and Economic Policies Book Series, Chapter 6, pp. 165-204. Central Bank of Chile.

Mian, A., L. Straub, and A. Sufi (2020). The saving glut of the rich and the rise in household debt. Unpublished Manuscript.

Mian, A., L. Straub, and A. Sufi (2021). Indebted demand. Quarterly Journal of Economics 136(4), 2243-2307.

Mian, A. and A. Sufi (2018). Finance and business cycles: The credit-driven household demand channel. Journal of Economic Perspectives 32(3), 31-58.

Minsky, H. (1986). Stabilizing an unstable economy. New Haven, CT: Yale University Press.

Morelli, S. and A. Atkinson (2015). Inequality and crises revisited. Economia Politica: Journal of Analytical and Institutional Economics 32(1), 31-51. 
Mueller, K. and E. Verner (2021). Credit allocation and macroeconomic fluctuations. Unpublished Manuscript.

Paul, P. (2020). A macroeconomic model with occasional financial crises. Journal of Economic Dynamics and Control 112(1-21).

Paul, P. and J. Pedtke (2020). Historical patterns around financial crises. FRBSF Economic Letter 10.

Perugini, C., J. Hölscher, and S. Collie (2016). Inequality, credit and financial crises. Cambridge Journal of Economics 40(1), 227.

Piketty, T. and E. Saez (2003). Income inequality in the united states, 1913-1998. The Quarterly Journal of Economics 118(1), 1 .

Piketty, T., E. Saez, and G. Zucman (2018). Distributional national accounts: Methods and estimates for the United States. Quarterly Journal of Economics 133(2), 553-609.

Rajan, R. (2010). Fault lines: How hidden fractures still threaten the world economy (1 ed.). Princeton University Press.

Reinhart, C. M. and K. S. Rogoff (2009b). This time is different: A panoramic view of eight centuries of financial crises. Princeton University Press.

Richter, B., M. Schularick, and P. Wachtel (2021). When to lean against the wind. Journal of Money, Credit and Banking 53(1), 5-39.

Roine, J. and D. Waldenström (2015). Long-run trends in the distribution of income and wealth. Handbook of Income Distribution 2, 469 - 592.

Romer, C. D. and D. H. Romer (2017). New evidence on the aftermath of financial crises in advanced countries. American Economic Review 107(10), 3072-3118.

Romer, C. D. and D. H. Romer (2018). Why some times are different: Macroeconomic policy and the aftermath of financial crises. Economica 85, 1-40.

Saez, E. and G. Zucman (2016). Wealth inequality in the United States since 1913: Evidence from capitalized income tax data. The Quarterly Journal of Economics 131(2), 519.

Schularick, M. and A. M. Taylor (2012). Credit booms gone bust: Monetary policy, leverage cycles, and financial crises, 1870-2008. American Economic Review 102(2), 1029-1061. 


\section{Appendix: For Online Publication}

\section{A Data Description}

Tables A.1 and A.2 use the following country abbreviations: AUS=Australia, BEL=Belgium, $\mathrm{CAN}=$ Canada, $\mathrm{CHE}=$ Switzerland, $\mathrm{DEU}=$ Germany, $\mathrm{DNK}=$ Denmark, $\mathrm{ESP}=$ Spain, $\mathrm{FIN}=$ Finland, $\mathrm{FRA}=$ France, $\mathrm{GBR}=$ Great Britain, ITA $=$ Italy, JPN=Japan, NLD=Netherlands, NOR=Norway, $\mathrm{PRT}=$ Portugal, $\mathrm{SWE}=$ Sweden, $\mathrm{USA}=$ United States.

\section{A.1 Macro-Financial Data}

\begin{tabular}{lllllllllll}
\hline \hline & & & & & & & & \\
AUS & 1893 & 1989 & & & & & & \\
BEL & 1870 & 1885 & 1925 & 1931 & 1934 & 1939 & 2008 & & \\
CAN & 1907 & & & & & & & & \\
CHE & 1870 & 1910 & 1931 & 1991 & 2008 & & & & \\
DEU & 1873 & 1891 & 1901 & 1907 & 1931 & 2008 & & & \\
DNK & 1877 & 1885 & 1908 & 1921 & 1931 & 1987 & 2008 & & \\
ESP & 1883 & 1890 & 1913 & 1920 & 1924 & 1931 & 1977 & 2008 & \\
FIN & 1877 & 1900 & 1921 & 1931 & 1991 & & & & \\
FRA & 1882 & 1889 & 1930 & 2008 & & & & & \\
GBR & 1890 & 1974 & 1991 & 2007 & & & & & \\
ITA & 1873 & 1887 & 1893 & 1907 & 1921 & 1930 & 1935 & 1990 & 2008 \\
JPN & 1871 & 1890 & 1907 & 1920 & 1927 & 1997 & & & \\
NLD & 1893 & 1907 & 1921 & 1939 & 2008 & & & & \\
NOR & 1899 & 1922 & 1931 & 1988 & & & & & \\
PRT & 1890 & 1920 & 1923 & 1931 & 2008 & & & & \\
SWE & 1878 & 1907 & 1922 & 1931 & 1991 & 2008 & & & \\
USA & 1873 & 1893 & 1907 & 1929 & 1984 & 2007 & & & \\
& & & & & & & & & \\
\hline \hline
\end{tabular}

Table A.1: Financial Crises Dates from Jordà et al. (2017). 


\begin{tabular}{|c|c|c|c|c|c|c|c|c|c|c|c|c|c|c|c|}
\hline \multirow[t]{3}{*}{ AUS } & $\mathrm{F}$ & 1891 & 1894 & 1989 & & & & & & & & & & & \\
\hline & $\mathrm{N}$ & 1875 & 1878 & 1881 & 1883 & 1885 & 1887 & 1889 & 1896 & 1898 & 1900 & 1904 & 1910 & 1913 & 1926 \\
\hline & & 1938 & 1943 & 1951 & 1956 & 1961 & 1973 & 1976 & 1981 & 2008 & & & & & \\
\hline \multirow[t]{2}{*}{ BEL } & $\mathrm{F}$ & 1870 & 1883 & 1926 & 1930 & 1937 & 2008 & & & & & & & & \\
\hline & $\mathrm{N}$ & 1872 & 1874 & 1887 & 1890 & 1900 & 1913 & 1916 & 1942 & 1951 & 1957 & 1974 & 1980 & 1992 & \\
\hline \multirow{3}{*}{ CAN } & $\mathrm{F}$ & 1907 & & & & & & & & & & & & & \\
\hline & $\mathrm{N}$ & 1871 & 1874 & 1877 & 1882 & 1884 & 1888 & 1891 & 1894 & 1903 & 1913 & 1917 & 1928 & 1944 & 1947 \\
\hline & & 1953 & 1956 & 1981 & 1989 & 2008 & & & & & & & & & \\
\hline \multirow[t]{3}{*}{ CHE } & $\mathrm{F}$ & 1871 & 1929 & 1990 & 2008 & & & & & & & & & & \\
\hline & $\mathrm{N}$ & 1875 & 1880 & 1886 & 1890 & 1893 & 1899 & 1902 & 1906 & 1912 & 1916 & 1920 & 1933 & 1939 & 1947 \\
\hline & & 1951 & 1957 & 1974 & 1981 & 1994 & 2001 & & & & & & & & \\
\hline \multirow[t]{2}{*}{ DEU } & $\mathrm{F}$ & 1875 & 1890 & 1908 & 1928 & 2008 & & & & & & & & & \\
\hline & $\mathrm{N}$ & 1879 & 1898 & 1905 & 1913 & 1922 & 1943 & 1966 & 1974 & 1980 & 1992 & 2001 & & & \\
\hline \multirow[t]{2}{*}{ DNK } & $\mathrm{F}$ & 1872 & 1876 & 1883 & 1920 & 1931 & 1987 & 2008 & & & & & & & \\
\hline & $\mathrm{N}$ & 1870 & 1880 & 1887 & 1911 & 1914 & 1916 & 1923 & 1939 & 1944 & 1950 & 1962 & 1973 & 1979 & 1992 \\
\hline \multirow[t]{3}{*}{ ESP } & $\mathrm{F}$ & 1883 & 1889 & 1913 & 1925 & 1929 & 1978 & 2007 & & & & & & & \\
\hline & $\mathrm{N}$ & 1873 & 1877 & 1892 & 1894 & 1901 & 1909 & 1911 & 1916 & 1927 & 1932 & 1935 & 1940 & 1944 & 1947 \\
\hline & & 1952 & 1958 & 1974 & 1980 & 1992 & & & & & & & & & \\
\hline \multirow[t]{2}{*}{ FIN } & $\mathrm{F}$ & 1876 & 1900 & 1929 & 1989 & & & & & & & & & & \\
\hline & $\mathrm{N}$ & 1870 & 1883 & 1890 & 1898 & 1907 & 1913 & 1916 & 1938 & 1941 & 1943 & 1952 & 1957 & 1975 & 2008 \\
\hline \multirow{3}{*}{ FRA } & $\mathrm{F}$ & 1882 & 1929 & 2007 & & & & & & & & & & & \\
\hline & $\mathrm{N}$ & 1872 & 1874 & 1892 & 1894 & 1896 & 1900 & 1905 & 1907 & 1909 & 1912 & 1916 & 1920 & 1926 & 1933 \\
\hline & & 1937 & 1939 & 1942 & 1974 & 1992 & & & & & & & & & \\
\hline \multirow[t]{3}{*}{ GBR } & $\mathrm{F}$ & 1873 & 1889 & 1973 & 1990 & 2007 & & & & & & & & & \\
\hline & $\mathrm{N}$ & 1871 & 1875 & 1877 & 1883 & 1896 & 1899 & 1902 & 1907 & 1918 & 1925 & 1929 & 1938 & 1943 & 1951 \\
\hline & & 1957 & 1979 & & & & & & & & & & & & \\
\hline \multirow[t]{2}{*}{ ITA } & $\mathrm{F}$ & 1874 & 1887 & 1891 & 1929 & 1992 & 2007 & & & & & & & & \\
\hline & $\mathrm{N}$ & 1870 & 1883 & 1897 & 1918 & 1923 & 1925 & 1932 & 1939 & 1974 & 2002 & 2004 & & & \\
\hline \multirow[t]{3}{*}{ JPN } & $\mathrm{F}$ & 1882 & 1901 & 1907 & 1913 & 1925 & 1997 & & & & & & & & \\
\hline & $\mathrm{N}$ & 1875 & 1877 & 1880 & 1887 & 1890 & 1892 & 1895 & 1898 & 1903 & 1919 & 1921 & 1929 & 1933 & 1940 \\
\hline & & 1973 & 2001 & 2007 & & & & & & & & & & & \\
\hline \multirow[t]{2}{*}{ NLD } & $\mathrm{F}$ & 1892 & 1906 & 1937 & 1939 & 2008 & & & & & & & & & \\
\hline & $\mathrm{N}$ & 1870 & 1873 & 1877 & 1889 & 1894 & 1899 & 1902 & 1913 & 1929 & 1957 & 1974 & 1980 & 2001 & \\
\hline \multirow[t]{2}{*}{ NOR } & $\mathrm{F}$ & 1897 & 1920 & 1930 & 1987 & & & & & & & & & & \\
\hline & $\mathrm{N}$ & 1876 & 1881 & 1885 & 1893 & 1902 & 1916 & 1923 & 1939 & 1941 & 1957 & 1981 & 2007 & & \\
\hline \multirow[t]{3}{*}{ PRT } & $\mathrm{F}$ & 1890 & 1923 & 1929 & 2008 & & & & & & & & & & \\
\hline & $\mathrm{N}$ & 1870 & 1873 & 1877 & 1888 & 1893 & 1900 & 1904 & 1907 & 1912 & 1914 & 1916 & 1925 & 1927 & 1934 \\
\hline & & 1937 & 1939 & 1941 & 1944 & 1947 & 1951 & 1973 & 1982 & 1992 & 2002 & 2004 & & & \\
\hline \multirow[t]{3}{*}{ SWE } & $\mathrm{F}$ & 1879 & 1907 & 1920 & 1930 & 1990 & 2007 & & & & & & & & \\
\hline & $\mathrm{N}$ & 1873 & 1876 & 1881 & 1883 & 1885 & 1888 & 1890 & 1899 & 1901 & 1904 & 1913 & 1916 & 1924 & 1939 \\
\hline & & 1976 & 1980 & & & & & & & & & & & & \\
\hline \multirow[t]{3}{*}{ USA } & $\mathrm{F}$ & 1873 & 1882 & 1892 & 1906 & 1929 & 2007 & & & & & & & & \\
\hline & $\mathrm{N}$ & 1875 & 1887 & 1889 & 1895 & 1901 & 1909 & 1913 & 1916 & 1918 & 1926 & 1937 & 1944 & 1948 & 1953 \\
\hline & & 1957 & 1969 & 1973 & 1979 & 1981 & 1990 & 2000 & & & & & & & \\
\hline
\end{tabular}

Table A.2: Business Cycle Peaks based on Jordà et al. (2013) and the Bry and Boschan (1971) algorithm. ' $F$ ' denotes a financial recession, ' $N$ ' denotes a nonfinancial recession. 


\section{A.2 Total Factor Productivity}

Utilization-Adjustment. I follow Imbs (1999) and adjust TFP for the utilization of the input factors. Following the notation in Section 2.2, consider the production function

$$
Y_{t}=A_{t}\left(u_{t} K_{t}\right)^{\alpha}\left(e_{t} H_{t}\right)^{1-\alpha}
$$

where $u_{t}$ and $e_{t}$ denote capital utilization and labor effort, respectively. Using a partial equilibrium model of factor hoarding, Imbs (1999) shows how to obtain country-specific time series for $u_{t}$ and $e_{t}$ as functions of observables. In particular, these are given by

$$
\begin{aligned}
& u_{t}=\left(\frac{\frac{Y_{t}}{K_{t}}}{\left.\frac{Y}{K}\right|_{s s}}\right)^{\frac{\delta}{\delta+r}}, \\
& e_{t}=\left(\alpha \frac{Y_{t}}{C_{t}}\right)^{\frac{1}{1+\psi}},
\end{aligned}
$$

where $\delta$ denotes the rate of depreciation (assumed to equal 0.1), $r$ is the real interest rate (calibrated to 0.04$)$, and $Y / K_{\mid S S}$ is the country-specific average output-to-capital ratio. $C_{t}$ denotes real consumption and

$$
\begin{aligned}
& \alpha=1-\left.\frac{K}{Y}\right|_{\mid s s}(r+\delta), \\
& \psi=\frac{\alpha}{L S_{\mid s s}}-1
\end{aligned}
$$

where $K / Y_{\mid s s}$ is the country-specific average capital-to-output ratio and $L S_{\mid s s}$ is the country-specific average labor share. I collect the necessary data on private capital stocks from the IMF's Investment and Capital Stock data set, and on GDP, the labor share, the number of employed people, consumption, and average hours worked from the Penn World Table (Version 9.0; Feenstra et al., 2015). The utilization adjustment is derived by comparing the utilization-adjusted TFP with the unadjusted one. Since the data are only available from 1960 onward, I run country-specific regressions using the percentage change in total hours worked to predict the derived utilization adjustment. Based on the coefficients from this estimation, I use the predicted values for the whole sample to adjust the original TFP series by Bergeaud et al. (2016). As a robustness check, I compare the utilization adjustment for the United States to the one derived by Fernald (2014), who uses sector-specific data instead of economy-wide aggregates. The two series are highly correlated with a correlation coefficient of 0.79 , both shown in Figure A.1. 


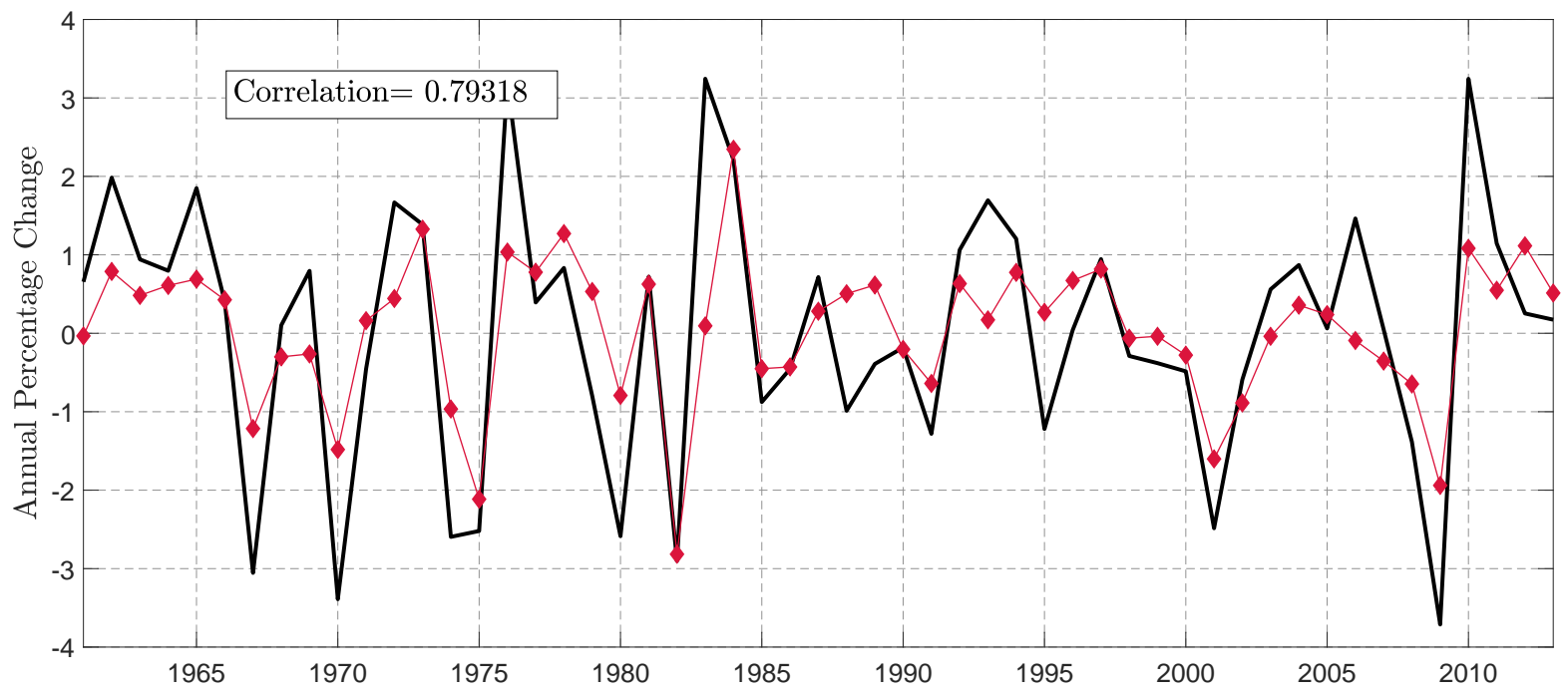

Figure A.1: Comparison of utilization adjustment for the U.S. Solid black series denotes the utilization adjustment by Fernald (2014) and red series with diamond markers denotes the utilization adjustment based on the approach by Imbs (1999).

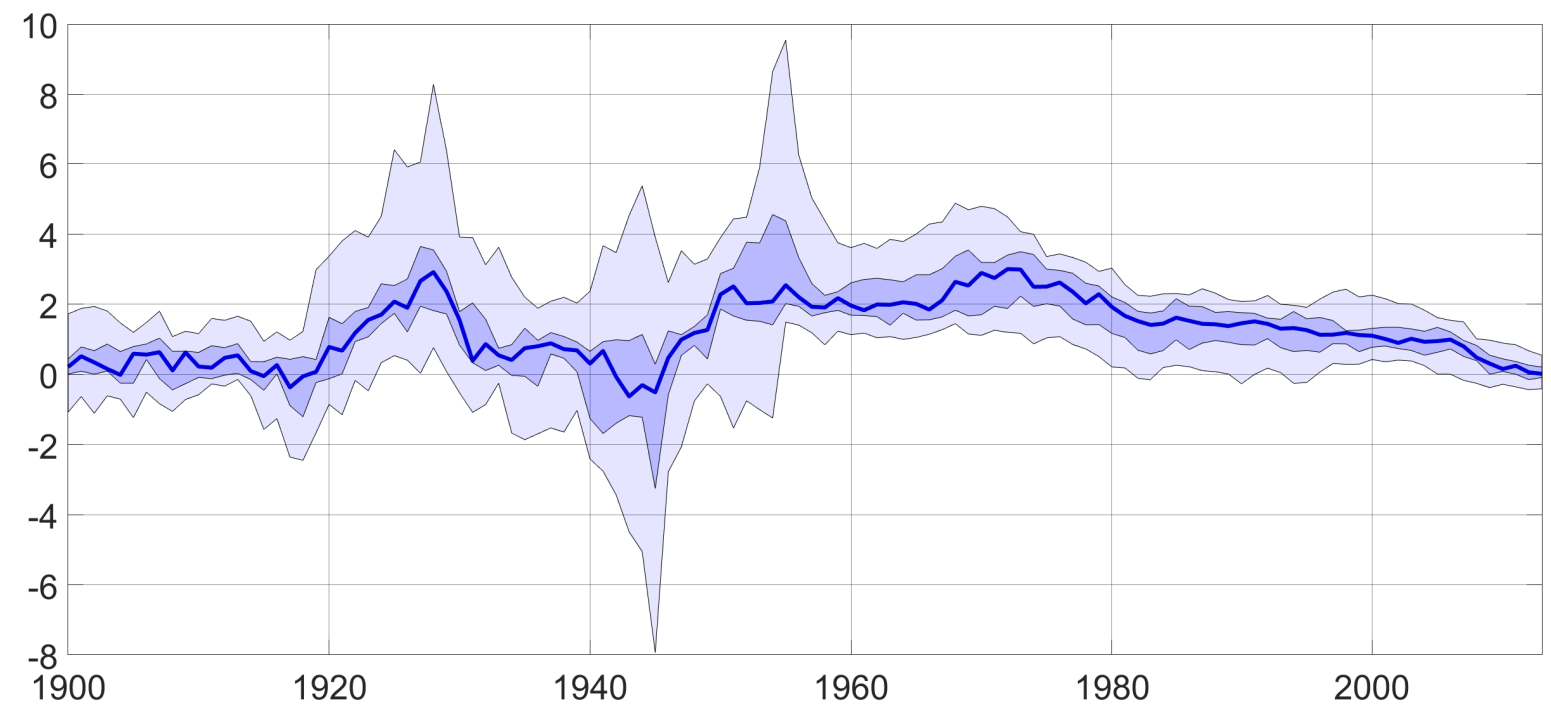

Figure A.2: Ten-Year Moving Average of Util.-adj. TFP Growth. Median, $33^{\text {rd }}, 66^{\text {th }}$, $90^{\text {th }}$, and $10^{\text {th }}$ percentiles shown. 


\section{B Predicting Financial Crises - Additional Evidence}

\section{B.1 Income Inequality}

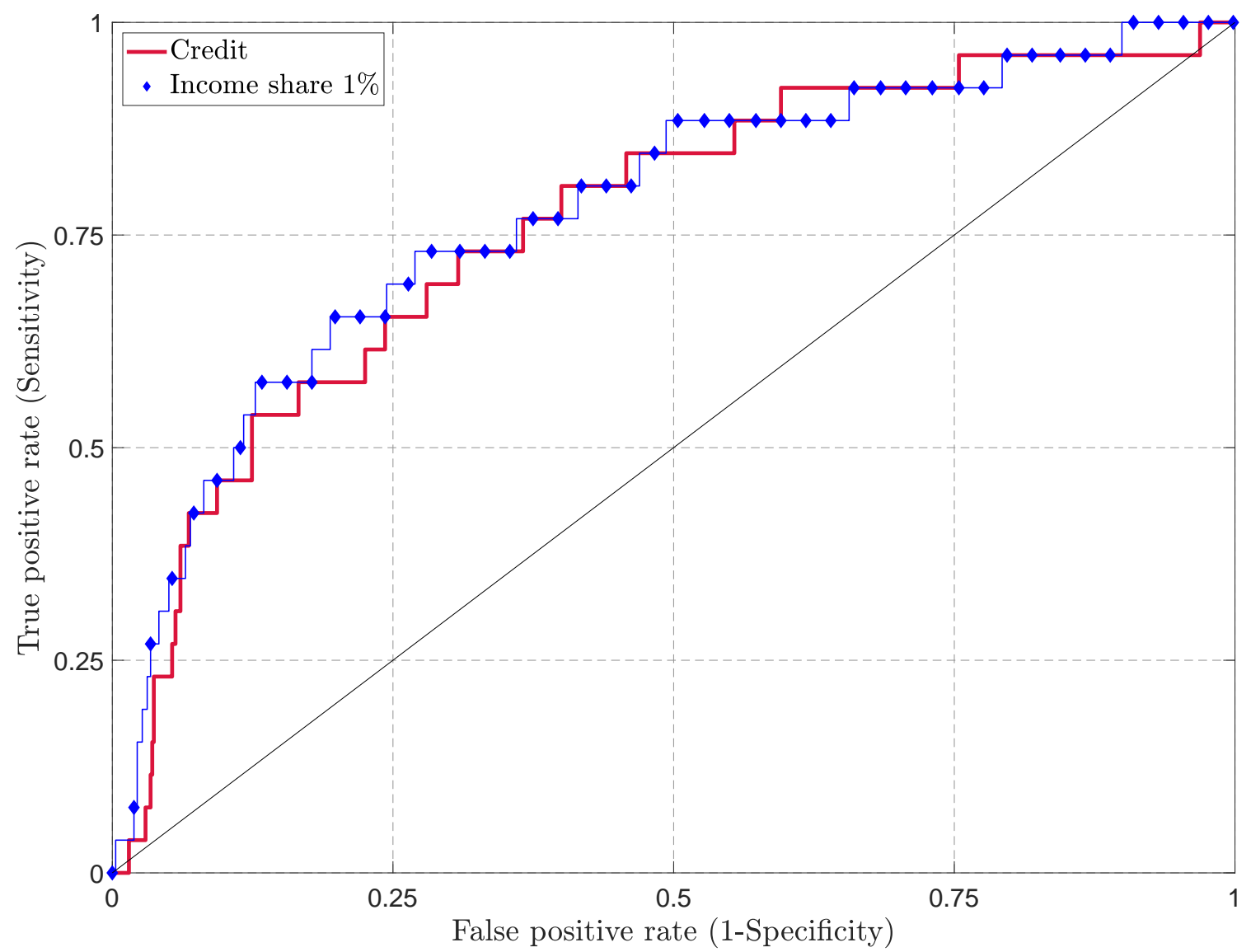

Figure B.1: ROC Comparison. Comparison of receiver operating characteristic curve for logistic probability models in columns 1 and 2 in Table 1 . The area under the ROC is 0.764 for the model in column 1 (credit) and 0.777 for the model in column 2 (top 1\% income share). 


\begin{tabular}{|c|c|c|c|c|c|c|}
\hline & $\begin{array}{c}(1) \\
\text { Baseline }\end{array}$ & $\begin{array}{c}(2) \\
\text { Pre-WWII }\end{array}$ & $\begin{array}{c}(3) \\
\text { Post-WWII }\end{array}$ & $\begin{array}{c}\text { (4) } \\
\text { Great Recession } \\
\text { \& Depression }\end{array}$ & $\begin{array}{c}(5) \\
\text { Financial } \\
\text { Recessions }\end{array}$ & $\begin{array}{c}(6) \\
\text { Nonfinancial } \\
\text { Recessions }\end{array}$ \\
\hline$\Delta_{4} \log (\text { Credit })_{t-1}$ & $\begin{array}{l}0.529^{* * *} \\
(0.191) \\
{[0.013]}\end{array}$ & $\begin{array}{c}0.435^{*} \\
(0.257) \\
{[0.025]}\end{array}$ & $\begin{array}{l}0.712^{* *} \\
(0.322) \\
{[0.011]}\end{array}$ & $\begin{array}{c}0.429^{*} \\
(0.245) \\
{[0.010]}\end{array}$ & $\begin{array}{l}0.569^{* * *} \\
(0.182) \\
{[0.014]}\end{array}$ & $\begin{array}{c}0.020 \\
(0.108) \\
{[0.001]}\end{array}$ \\
\hline$\Delta_{4}$ Income Share $1 \%_{t-1}$ & $\begin{array}{l}0.663^{* * *} \\
(0.181) \\
{[0.016]}\end{array}$ & $\begin{array}{c}0.476 \\
(0.306) \\
{[0.028]}\end{array}$ & $\begin{array}{l}0.851^{* * *} \\
(0.295) \\
{[0.013]}\end{array}$ & $\begin{array}{l}0.452^{* *} \\
(0.188) \\
{[0.010]}\end{array}$ & $\begin{array}{l}0.725^{* * *} \\
(0.194) \\
{[0.018]}\end{array}$ & $\begin{array}{c}-0.216^{*} \\
(0.129) \\
{[-0.013]}\end{array}$ \\
\hline $\begin{array}{l}\text { Number of crises / recessions } \\
\text { Observations } \\
\text { Countries } \\
\text { Country FE } \\
\quad \text {-value } \\
\text { Pseudo } R^{2} \\
\text { AUROC }\end{array}$ & $\begin{array}{c}31 \\
846 \\
15 \\
\checkmark \\
0.945 \\
0.105 \\
0.791^{* * *} \\
(0.041)\end{array}$ & $\begin{array}{c}10 \\
135 \\
7 \\
\checkmark \\
0.996 \\
0.058 \\
0.722^{* * *} \\
(0.079)\end{array}$ & $\begin{array}{c}21 \\
681 \\
15 \\
\checkmark \\
0.938 \\
0.151 \\
0.815^{* * *} \\
(0.054)\end{array}$ & $\begin{array}{c}17 \\
536 \\
10 \\
\checkmark \\
0.834 \\
0.080 \\
0.754^{* * *} \\
(0.057)\end{array}$ & $\begin{array}{c}33 \\
846 \\
15 \\
\checkmark \\
0.916 \\
0.115 \\
0.811^{* * *} \\
(0.034)\end{array}$ & $\begin{array}{c}68 \\
918 \\
16 \\
\checkmark \\
0.510 \\
0.035 \\
0.645^{* * *} \\
(0.034)\end{array}$ \\
\hline
\end{tabular}

Table B.1: Predicting Financial Crises - Robustness. Results from logit regressions (1). Column (1) replicates the baseline regression in column (4) of Table 1. Columns (2) and (3) restrict the estimation to a pre-WWII or post-WWII sample, respectively. Column (4) excludes the Great Depression and the Great Recession from the sample. Columns (5) and (6) consider financial and nonfinancial recession indicators as dependent variables. Notation: Robust standard errors in parentheses, marginal effects at mean in square brackets, the $p$-value refers to a test on the joint significance of the country-fixed effects, ${ }^{* * *} p<0.01$, ${ }^{* *} p<0.05,{ }^{*} p<0.1$. 


\begin{tabular}{lcccc}
\hline & $\begin{array}{c}(1) \\
\text { Reinhart-Rogoff }\end{array}$ & $\begin{array}{c}(2) \\
\text { Bordo-et-al. }\end{array}$ & $\begin{array}{c}(3) \\
\text { Laeven-Valencia }\end{array}$ & $\begin{array}{c}(4) \\
\text { Romer-Romer }\end{array}$ \\
\hline$\Delta_{4} \log (\text { Credit })_{\mathrm{t}-1}$ & $0.382^{* *}$ & $1.151^{* *}$ & $0.364^{*}$ & $0.500^{* *}$ \\
& $(0.154)$ & $(0.450)$ & $(0.187)$ & $(0.233)$ \\
& {$[0.010]$} & {$[0.018]$} & {$[0.009]$} & {$[0.018]$} \\
& & & & \\
$\Delta_{4}$ Income Share $1 \%_{\mathrm{t}-1}$ & $0.585^{* * *}$ & $0.724^{* *}$ & $0.428^{* *}$ & $0.387^{* *}$ \\
& $(0.164)$ & $(0.281)$ & $(0.198)$ & $(0.193)$ \\
& {$[0.016]$} & {$[0.012]$} & {$[0.010]$} & {$[0.014]$} \\
& & & & \\
& & & & \\
Number of crises & 34 & 16 & 19 & 29 \\
Observations & 885 & 458 & 625 & 16 \\
Countries & 16 & 14 & 12 & $\checkmark$ \\
Country FE & $\checkmark$ & $\checkmark$ & $\checkmark$ & 0.448 \\
$\quad$ p-value & 0.954 & 0.809 & 0.998 & 0.083 \\
Pseudo R & 0.083 & 0.159 & 0.051 & $0.733^{* * *}$ \\
AUROC & $0.742^{* * *}$ & $0.812^{* * *}$ & $0.711^{* * *}$ & $(0.044)$ \\
& $(0.044)$ & $(0.065)$ & $(0.054)$ & \\
\hline \hline
\end{tabular}

Table B.2: Predicting Financial Crises - Alternative Financial Crises Dates. Results from logit regressions (1) using alternative financial crises dates by Reinhart and Rogoff (2009b) (column 1), Bordo et al. (2001) (column 2), Laeven and Valencia (2013) (column 3), and Romer and Romer (2017) (column 4). Notation: Robust standard errors in parentheses, marginal effects at mean in square brackets, the p-value refers to a test on the joint significance of the country-fixed effects, ${ }^{* * *} p<0.01,{ }^{* *} p<0.05,{ }^{*} p<0.1$. 


\section{B.2 Wealth-to-Income Ratio}

\begin{tabular}{lcc}
\hline & $(1)$ & $(2)$ \\
\hline & & \\
$\Delta_{4}$ Wealth-to-income Ratio $_{\mathrm{t}-1}$ & $0.538^{* *}$ & 0.345 \\
& $(0.235)$ & $(0.277)$ \\
& {$[0.018]$} & {$[0.010]$} \\
& & \\
$\Delta_{4} \log (\text { House Prices) })_{\mathrm{t}-1}$ & & $0.379^{*}$ \\
& & $(0.208)$ \\
& & {$[0.011]$} \\
& & \\
$\Delta_{4} \log (\text { Stock Prices) })_{\mathrm{t}-1}$ & & $0.464^{* *}$ \\
& & $(0.189)$ \\
& & {$[0.013]$} \\
& & \\
\hline Number of crises & & \\
Observations & 28 & 28 \\
Countries & 700 & 700 \\
Country FE & 12 & 12 \\
$\quad p$-value & $\checkmark$ & $\checkmark$ \\
Pseudo R & & \\
AUROC & 0.996 & 0.976 \\
& 0.044 & 0.080 \\
& $0.661^{* * *}$ & $0.729^{* * *}$ \\
\hline \hline & $(0.057)$ & $(0.052)$ \\
\hline
\end{tabular}

Table B.3: Predicting Financial Crises - Wealth-to-Income Ratio. Results from logit regressions (1) with binary financial crisis indicator as dependent variable. Stock and house prices in column (2) are deflated using a consumer price index. The estimations cover the years 1875-2013. Notation: Robust standard errors in parentheses, marginal effects at mean in square brackets, the p-value refers to a test on the joint significance of the country-fixed effects, ${ }^{* * *} p<0.01,{ }^{* *} p<0.05,{ }^{*} p<0.1$. 


\section{B.3 Productivity}

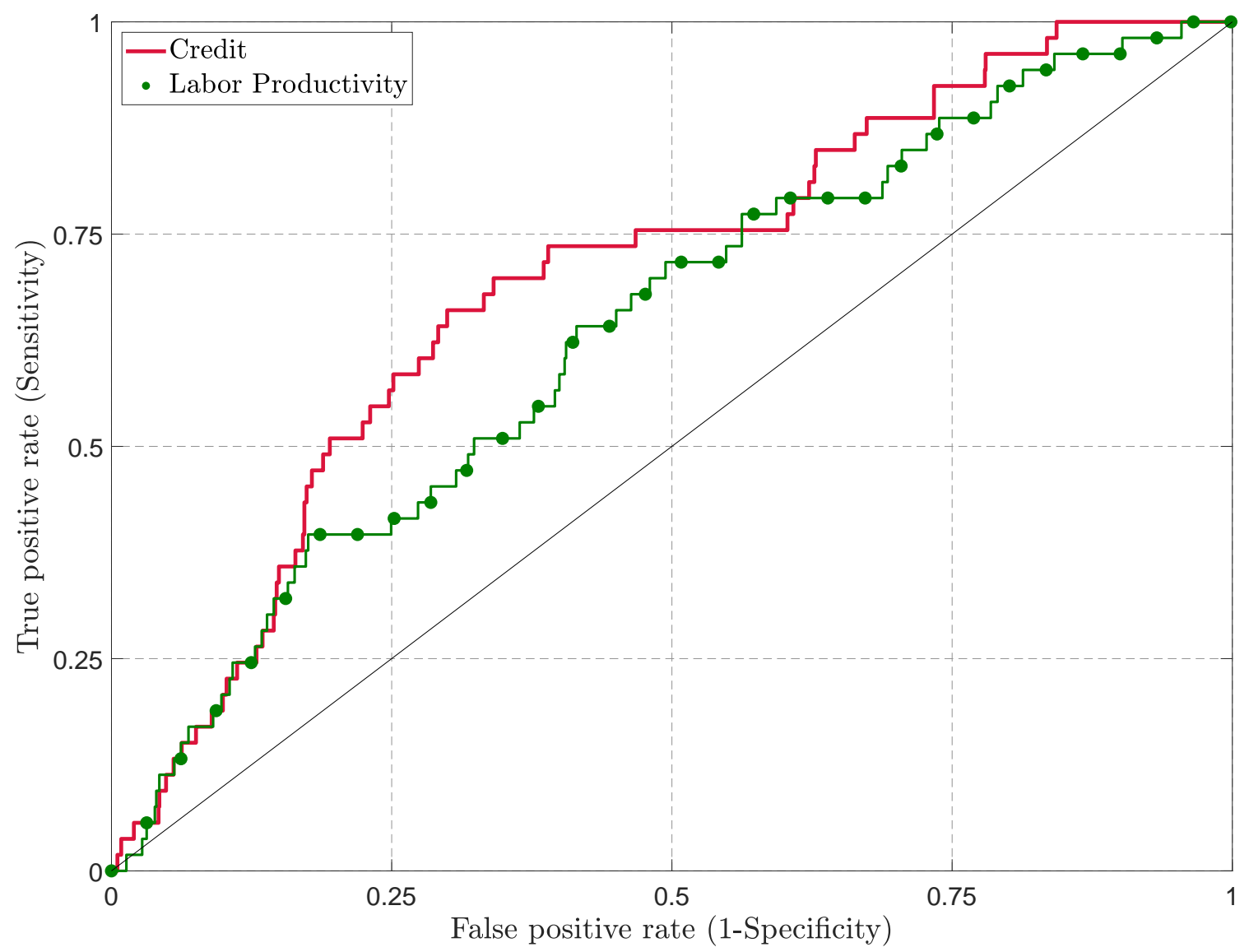

Figure B.2: ROC Comparison. Comparison of receiver operating characteristic curve for logistic probability models in columns 1 and 3 in Table 3. The area under the ROC is 0.695 for the model in column 1 (credit) and 0.636 for the model in column 3 (labor productivity). 


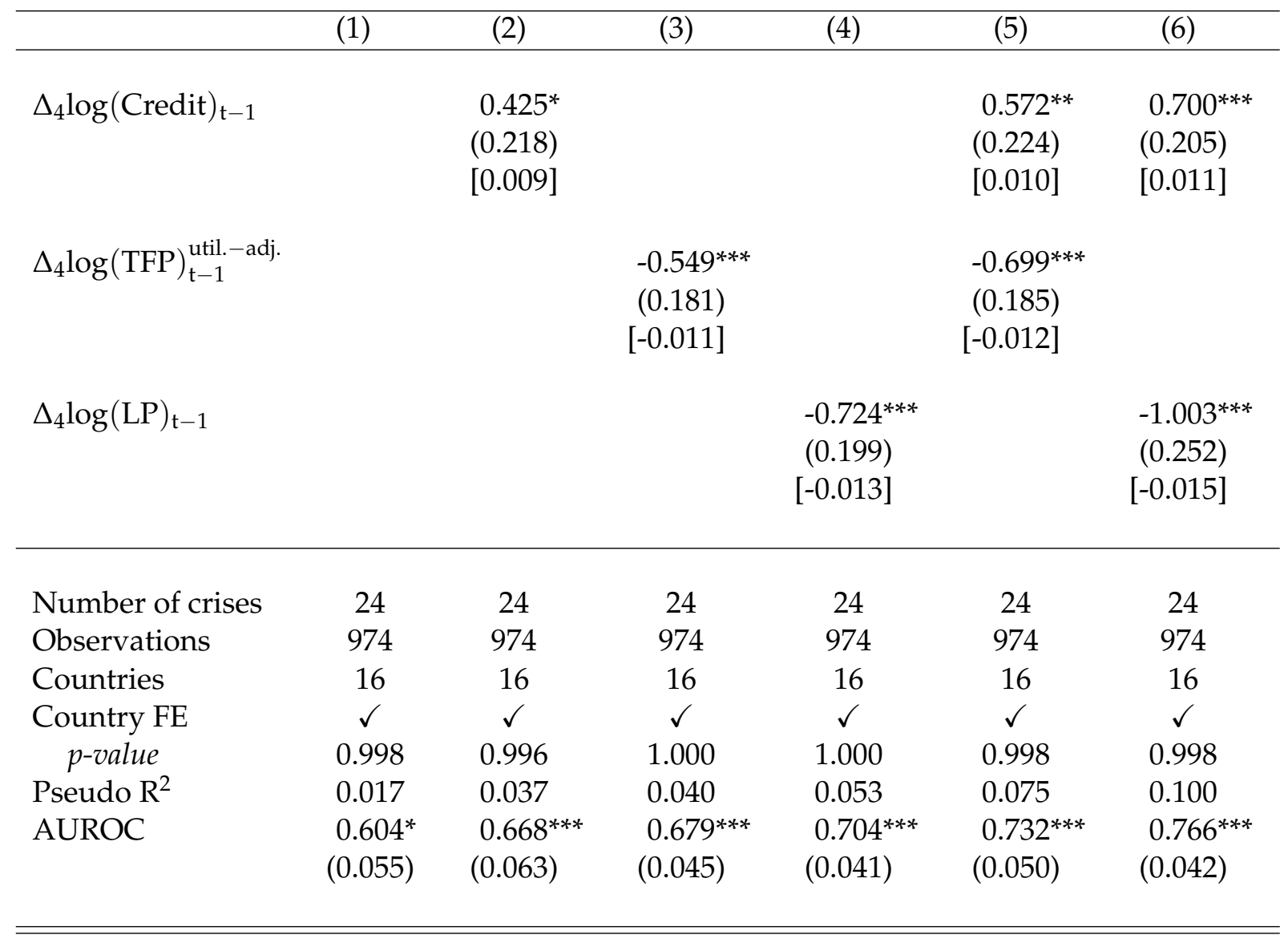

Table B.4: Predicting Financial Crises - Post-WWII. Results from logit regressions (1) with binary financial crisis indicator as dependent variable. The sample is restricted to the post-WWII era (1946-2013). Column (1) includes only country-fixed effects. Notation: Robust standard errors in parentheses, marginal effects at mean in square brackets, the p-value refers to a test on the joint significance of the country-fixed effects, ${ }^{* * *} p<0.01,{ }^{* *} p<0.05,{ }^{*} p<0.1$. 


\begin{tabular}{|c|c|c|c|c|c|c|}
\hline & $\begin{array}{c}(1) \\
\text { Baseline }\end{array}$ & $\begin{array}{c}(2) \\
\text { Pre-WWII }\end{array}$ & $\begin{array}{c}\text { (3) } \\
\text { Post-WWII }\end{array}$ & $\begin{array}{c}(4) \\
\text { Financial } \\
\text { Recessions }\end{array}$ & $\begin{array}{c}(5) \\
\text { Nonfinancial } \\
\text { Recessions }\end{array}$ & $\begin{array}{l}\text { (6) } \\
\text { Input } \\
\text { Factors }\end{array}$ \\
\hline$\Delta_{4} \log (\text { Credit })_{t-1}$ & $\begin{array}{l}0.364^{* * *} \\
(0.105) \\
{[0.011]}\end{array}$ & $\begin{array}{l}0.334^{* * *} \\
(0.127) \\
{[0.016]}\end{array}$ & $\begin{array}{l}0.700^{* * *} \\
(0.205) \\
{[0.011]}\end{array}$ & $\begin{array}{l}0.326^{* * *} \\
(0.110) \\
{[0.009]}\end{array}$ & $\begin{array}{c}0.082 \\
(0.082) \\
{[0.007]}\end{array}$ & $\begin{array}{l}0.433^{* * *} \\
(0.134) \\
{[0.012]}\end{array}$ \\
\hline$\Delta_{4} \log (\mathrm{LP})_{\mathrm{t}-1}$ & $\begin{array}{l}-0.352^{* * *} \\
(0.101) \\
{[-0.010]}\end{array}$ & $\begin{array}{c}0.249 \\
(0.151) \\
{[0.012]}\end{array}$ & $\begin{array}{l}-1.003^{* * *} \\
(0.252) \\
{[-0.015]}\end{array}$ & $\begin{array}{l}-0.283^{* * *} \\
(0.096) \\
{[-0.008]}\end{array}$ & $\begin{array}{c}-0.119 \\
(0.092) \\
{[-0.010]}\end{array}$ & \\
\hline$\Delta_{4} \log (\text { Input Factors })_{t-1}$ & & & & & & $\begin{array}{c}0.103 \\
(0.145) \\
{[0.003]}\end{array}$ \\
\hline $\begin{array}{l}\text { Number of crises / recessions } \\
\text { Observations } \\
\text { Countries } \\
\text { Country FE } \\
\quad \text {-value } \\
\text { Pseudo }{ }^{2} \\
\text { AUROC }\end{array}$ & $\begin{array}{c}63 \\
1734 \\
17 \\
\checkmark \\
0.890 \\
0.051 \\
0.705^{* * *} \\
(0.032)\end{array}$ & $\begin{array}{c}39 \\
666 \\
16 \\
\checkmark \\
0.910 \\
0.050 \\
0.699^{* * *} \\
(0.040)\end{array}$ & $\begin{array}{c}24 \\
974 \\
16 \\
\checkmark \\
0.998 \\
0.100 \\
0.766^{* * *} \\
(0.042)\end{array}$ & $\begin{array}{c}60 \\
1734 \\
17 \\
\checkmark \\
0.959 \\
0.043 \\
0.692^{* * *} \\
(0.032)\end{array}$ & $\begin{array}{c}172 \\
1734 \\
17 \\
\checkmark \\
0.465 \\
0.017 \\
0.596^{* * *} \\
(0.023)\end{array}$ & $\begin{array}{c}53 \\
1552 \\
17 \\
\checkmark \\
0.963 \\
0.045 \\
0.695^{* * *} \\
(0.035)\end{array}$ \\
\hline
\end{tabular}

Table B.5: Predicting Financial Crises - Robustness. Results from logit regressions (1). Column (1) replicates the baseline regression in column (5) of Table 3. Columns (2) and (3) restrict the estimation to a pre-WWII or post-WWII sample, respectively. Columns (4) and (5) consider financial and nonfinancial recession indicators as dependent variables. Column (6) includes the input factors as a separate regressor (see text for details). Notation: Robust standard errors in parentheses, marginal effects at mean in square brackets, the $p$-value refers to a test on the joint significance of the country-fixed effects, ${ }^{* * *} p<0.01$, ${ }^{* *} p<0.05,{ }^{*} p<0.1$. 


\begin{tabular}{lcccc}
\hline & $\begin{array}{c}(1) \\
\text { Reinhart-Rogoff }\end{array}$ & $\begin{array}{c}(2) \\
\text { Bordo-et-al. }\end{array}$ & $\begin{array}{c}(3) \\
\text { Laeven-Valencia }\end{array}$ & $\begin{array}{c}(4) \\
\text { Romer-Romer }\end{array}$ \\
\hline$\Delta_{4} \log (\text { Credit })_{\mathrm{t}-1}$ & 0.194 & $0.740^{* *}$ & $0.281^{* *}$ & $0.479^{* *}$ \\
& $(0.136)$ & $(0.294)$ & $(0.110)$ & $(0.207)$ \\
& {$[0.007]$} & {$[0.015]$} & {$[0.007]$} & {$[0.013]$} \\
& & & & \\
$\Delta_{4} \log (\mathrm{LP})_{\mathrm{t}-1}$ & $-0.228^{* *}$ & $-0.615^{* *}$ & $-0.308^{* * *}$ & $-0.925^{* * *}$ \\
& $(0.101)$ & $(0.248)$ & $(0.119)$ & $(0.190)$ \\
& {$[-0.008]$} & {$[-0.012]$} & {$[-0.008]$} & {$[-0.025]$} \\
& & & & \\
\hline & & & & \\
Number of crises & 68 & 18 & 44 & 776 \\
Observations & 1682 & 630 & 1364 & 17 \\
Countries & 17 & 15 & 16 & $\checkmark$ \\
Country FE & $\checkmark$ & $\checkmark$ & $\checkmark$ & 0.641 \\
$\quad$-value & 0.804 & 1.000 & 0.877 & 0.086 \\
Pseudo R & 0.030 & 0.077 & 0.042 & $0.753^{* * *}$ \\
AUROC & $0.651^{* * *}$ & $0.714^{* * *}$ & $0.687^{* * *}$ & $(0.036)$ \\
& $(0.033)$ & $(0.063)$ & $(0.038)$ & \\
\hline \hline
\end{tabular}

Table B.6: Predicting Financial Crises - Alternative Financial Crises Dates. Results from logit regressions (1) using alternative financial crises dates by Reinhart and Rogoff (2009b) (column 1), Bordo et al. (2001) (column 2), Laeven and Valencia (2013) (column 3), and Romer and Romer (2017) (column 4). Notation: Robust standard errors in parentheses, marginal effects at mean in square brackets, the p-value refers to a test on the joint significance of the country-fixed effects, ${ }^{* * *} p<0.01,{ }^{* *} p<0.05,{ }^{*} p<0.1$. 


\section{B.4 Horse Race}

\begin{tabular}{|c|c|c|c|c|c|c|}
\hline & (1) & (2) & (3) & (4) & (5) & (6) \\
\hline$\Delta_{4} \log (\text { Credit })_{\mathrm{t}-1}$ & $\begin{array}{l}0.446^{* * *} \\
(0.122) \\
{[0.013]}\end{array}$ & & & $\begin{array}{l}0.438^{* * *} \\
(0.123) \\
{[0.011]}\end{array}$ & $\begin{array}{l}0.551^{* * *} \\
(0.141) \\
{[0.015]}\end{array}$ & $\begin{array}{l}0.523^{* * *} \\
(0.137) \\
{[0.012]}\end{array}$ \\
\hline$\Delta_{4}$ Income Share $1 \%_{t-1}$ & & $\begin{array}{l}0.632^{* * * *} \\
(0.145) \\
{[0.017]}\end{array}$ & & $\begin{array}{l}0.628^{* * * *} \\
(0.152) \\
{[0.015]}\end{array}$ & & $\begin{array}{l}0.592^{* * *} \\
(0.151) \\
{[0.014]}\end{array}$ \\
\hline$\Delta_{4} \log (\mathrm{LP})_{\mathrm{t}-1}$ & & & $\begin{array}{c}-0.226^{*} \\
(0.131) \\
{[-0.007]}\end{array}$ & & $\begin{array}{l}-0.379^{* * *} \\
(0.128) \\
{[-0.010]}\end{array}$ & $\begin{array}{c}-0.291^{* *} \\
(0.123) \\
{[-0.007]}\end{array}$ \\
\hline $\begin{array}{l}\text { Number of crises } \\
\text { Observations } \\
\text { Countries } \\
\text { Pseudo R }{ }^{2} \\
\text { AUROC }\end{array}$ & $\begin{array}{c}31 \\
937 \\
17 \\
0.027 \\
0.674^{* * *} \\
(0.047)\end{array}$ & $\begin{array}{c}31 \\
937 \\
17 \\
0.049 \\
0.717^{* * *} \\
(0.042)\end{array}$ & $\begin{array}{c}31 \\
937 \\
17 \\
0.006 \\
0.586^{*} \\
(0.049)\end{array}$ & $\begin{array}{c}31 \\
937 \\
17 \\
0.074 \\
0.769^{* * *} \\
(0.035)\end{array}$ & $\begin{array}{c}31 \\
937 \\
17 \\
0.043 \\
0.709^{* * *} \\
(0.042)\end{array}$ & $\begin{array}{c}31 \\
937 \\
17 \\
0.084 \\
0.774^{* * *} \\
(0.034)\end{array}$ \\
\hline
\end{tabular}

Table B.7: Predicting Financial Crises - Horse Race. Results from logit regressions (1) with binary financial crisis indicator as dependent variable. The sample is restricted to be the same across all estimations and covers the years 1888-2013. Notation: Robust standard errors in parentheses, marginal effects at mean in square brackets, ${ }^{* * *} p<0.01,{ }^{* *} p<0.05,{ }^{*} p<0.1$. 


\section{Trend vs. Cycle - Additional Results}

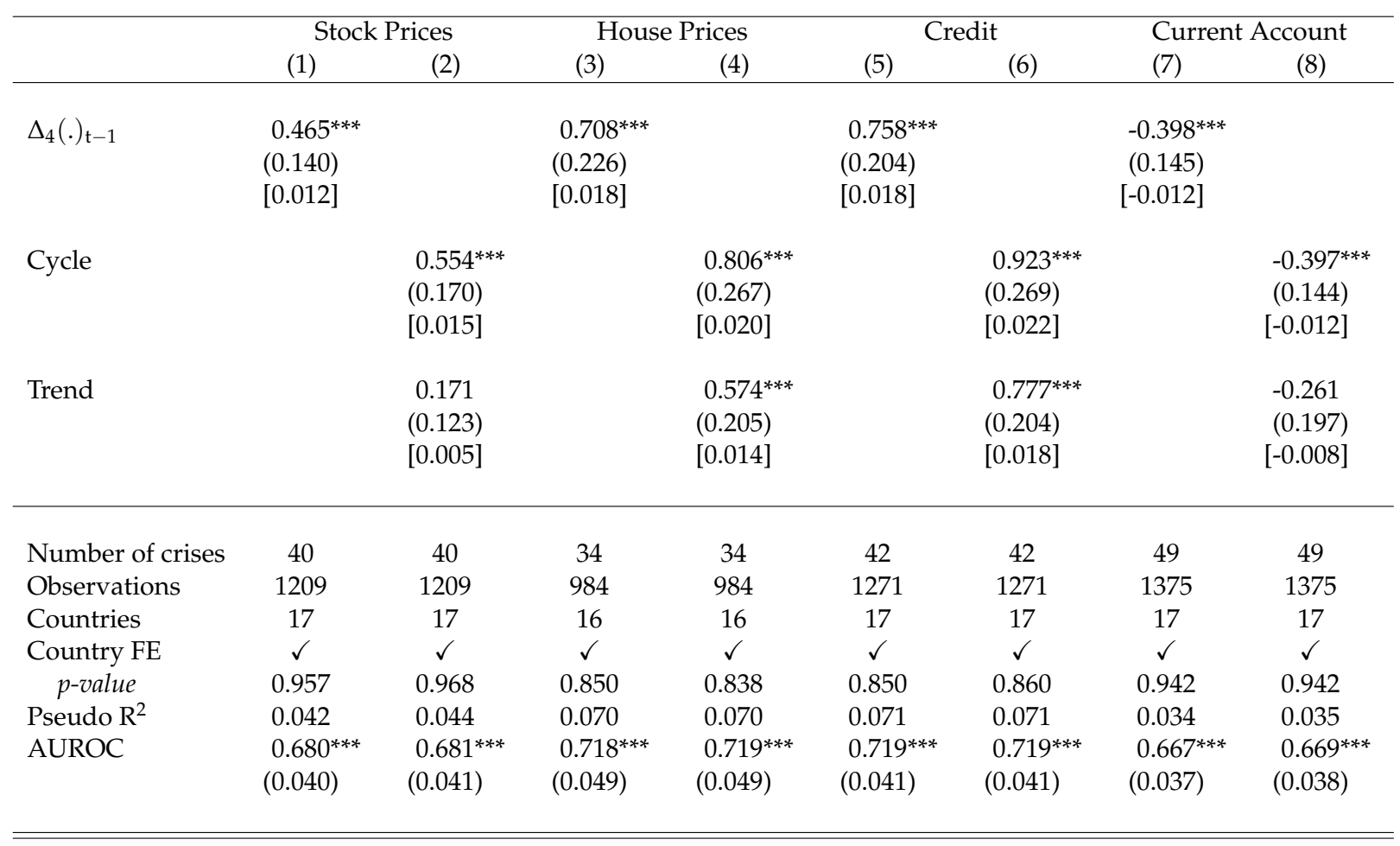

Table C.1: Predicting Financial Crises - Trend vs. Cycle. Results from logit regressions with binary financial crisis indicator as dependent variable. Linear regression $y_{t}=\hat{\alpha}+\hat{\beta}_{1} y_{t-5}+\hat{\beta}_{2} y_{t-6}+\hat{\beta}_{3} y_{t-7}+$ $\hat{\beta}_{4} y_{t-8}$ used to predict trend at time t following Hamilton (2018). Stock prices, house prices, and credit are deflated using a consumer price index and in logs, the current account is normalized by GDP. Notation: Robust standard errors in parentheses, marginal effects at mean in square brackets, the $p$-value refers to a test on the joint significance of the country-fixed effects, ${ }^{* * *} p<0.01,{ }^{* *} p<0.05,{ }^{*} p<0.1$. 


\section{Severity of Recessions}

\begin{tabular}{|c|c|c|c|c|c|c|}
\hline Year: $h$ & & 1 & 2 & 3 & 4 & 5 \\
\hline Average Recession & $\hat{\beta}^{h}$ & $\begin{array}{l}-1.917^{* * *} \\
(0.208)\end{array}$ & $\begin{array}{l}-1.277^{* * *} \\
(0.360)\end{array}$ & $\begin{array}{c}0.698 \\
(0.577)\end{array}$ & $\begin{array}{l}1.964^{* * *} \\
(0.688)\end{array}$ & $\begin{array}{l}3.518^{* * *} \\
(0.722)\end{array}$ \\
\hline$\Delta_{3}$ Income Share $1 \%{ }_{t}$ & $\hat{\gamma}^{h}$ & $\begin{array}{l}-0.081 \\
(0.226)\end{array}$ & $\begin{array}{l}-0.991^{* *} \\
(0.391)\end{array}$ & $\begin{array}{l}-0.766 \\
(0.627)\end{array}$ & $\begin{array}{l}-1.422^{*} \\
(0.747)\end{array}$ & $\begin{array}{l}-1.144 \\
(0.784)\end{array}$ \\
\hline Observations & & 98 & 98 & 98 & 98 & 98 \\
\hline
\end{tabular}

Table D.1: Behavior of GDP during Recessions - Pre-Recession Trends in the Top 1\% Income Share. Percentage change of GDP after the start of recessions. Notation: Standard errors in parentheses, ${ }^{* * *} p<$ $0.01,{ }^{* *} p<0.05,{ }^{*} p<0.1$.

\begin{tabular}{|c|c|c|c|c|c|c|}
\hline Year: $h$ & & 1 & 2 & 3 & 4 & 5 \\
\hline Average Recession & $\hat{\beta}^{h}$ & $\begin{array}{l}-1.909 * * * \\
(0.149)\end{array}$ & $\begin{array}{l}-0.763^{* * *} \\
(0.283)\end{array}$ & $\begin{array}{l}1.331^{* * *} \\
(0.391)\end{array}$ & $\begin{array}{l}2.767^{* * *} \\
(0.509)\end{array}$ & $\begin{array}{l}4.446^{* * *} \\
(0.569)\end{array}$ \\
\hline$\Delta_{3} \log (\mathrm{LP})_{\mathrm{t}}$ & $\hat{\gamma}^{h}$ & $\begin{array}{r}0.374^{*} \\
(0.204)\end{array}$ & $\begin{array}{c}0.573 \\
(0.388)\end{array}$ & $\begin{array}{l}1.550^{* * *} \\
(0.537)\end{array}$ & $\begin{array}{c}1.224^{*} \\
(0.699)\end{array}$ & $\begin{array}{c}0.898 \\
(0.780)\end{array}$ \\
\hline Observations & & 177 & 177 & 177 & 177 & 177 \\
\hline
\end{tabular}

Table D.2: Behavior of GDP during Recessions - Pre-Recession Trends in Labor Productivity. Percentage change of GDP after the start of recessions. Notation: Standard errors in parentheses, ${ }^{* * *} p<$ $0.01,{ }^{* *} p<0.05,{ }^{*} p<0.1$.

\section{E Data Appendix}

Acknowledgments. I am grateful to the following people for their help in constructing the data set and for the taking the time to answer my questions: Andre Decoster for Belgium, Michael Vaell for Canada, Charlotte Bartels for Germany, Matti Tuomala for Finland, Rolf Aaberge and Martin Jacob for Norway, Bertrand Garbinti for France, Salvatore Morelli for the United Kingdom, and Thomas Blanchet with respect to details of the World Inequality Database (WID). 


\section{Australia.}

\begin{tabular}{cc}
\hline Years & Top Income Shares with Capital Gains \\
\hline \hline $\begin{array}{c}\text { 1921-2013 } \\
\text { with interruptions }\end{array}$ & $\begin{array}{c}\text { WID-series based on Atkinson and Leigh (2007). } \\
\text { The series includes capital gains. }\end{array}$ \\
\hline Top Income Shares without Capital Gains \\
\hline 1970-2010 & $\begin{array}{c}\text { Corrected series from Burkhauser et al. (2015) } \\
\text { that excludes capital gains and imputation credits. }\end{array}$ \\
\hline I972-1985 & Important Capital Income Tax Laws \\
Cince 1986 & $\begin{array}{c}\text { Realized capital gains for assets held } \\
\text { less than one year were taxed. } \\
\text { Most realized capital gains were taxed, } \\
\text { regardless of how long the asset was held } \\
\text { (but only applying to assets purchased } \\
\text { after September 19, 1985). Owner-occupied } \\
\text { housing continued to be tax-exempt. }\end{array}$ \\
\hline
\end{tabular}

\section{Belgium.}

\begin{tabular}{cc}
\hline Years & \\
\hline \hline Top Income Shares without Capital Gains \\
\hline & Series based on Decoster et al. (2017). \\
Capital income is almost completely \\
missing, since most is taxed with a \\
withholding tax at the source and therefore \\
not declared in tax forms. In particular, \\
the series do not include capital gains.
\end{tabular}




\section{Canada.}

\begin{tabular}{|c|c|}
\hline \multicolumn{2}{|l|}{ Years } \\
\hline & Top Income Shares with Capital Gains \\
\hline 1920-1981 & WID-series based on Saez and Veall (2005), \\
\hline with interruptions & including capital gains since 1972 . \\
\hline \multirow[t]{5}{*}{$1982-2013$} & Market Income (incl. Cap. Gains) series from \\
\hline & Statistics Canada's Longitudinal Database. \\
\hline & The database is available at \\
\hline & https:/ / www150.statcan.gc.ca/t1/tbl1/en/tv.action?pid=1110005501. \\
\hline & Top Income Shares without Capital Gains \\
\hline \multirow[t]{4}{*}{$1920-1981$} & Series from Saez and Veall (2005) \\
\hline & that excludes capital gains. \\
\hline & The series can be found at \\
\hline & https:/ / eml.berkeley.edu/ saez/. \\
\hline \multirow[t]{5}{*}{$1982-2013$} & Market Income series from Statistics \\
\hline & Canada's Longitudinal Database. \\
\hline & The database is available at \\
\hline & https:/ / www150.statcan.gc.ca/t1/tbl1/en/tv.action?pid=1110005501. \\
\hline & Important Capital Income Tax Laws \\
\hline Before 1972 & $\begin{array}{l}\text { Realized capital gains were tax-exempt } \\
\text { and not reported on tax statements. }\end{array}$ \\
\hline Since 1972 & $\begin{array}{c}\text { Capital gains have been taxable to varying } \\
\text { degrees (see Saez and Veall (2005) for details). }\end{array}$ \\
\hline
\end{tabular}

\section{Switzerland.}

\begin{tabular}{cr}
\hline Years & \\
\hline \hline & Top Income Shares without Capital Gains \\
\hline 1933-2013 & WID-series based on Dell (2005), \\
with interruptions & $\begin{array}{r}\text { updated by Foellmi and Martínez (2017), } \\
\text { all series exclude capital gains. }\end{array}$ \\
\hline
\end{tabular}




\section{Germany.}

\begin{tabular}{cc}
\hline Years & Top Income Shares with Capital Gains \\
\hline $\begin{array}{c}\text { 1871-2013 } \\
\text { With interruptions }\end{array}$ & $\begin{array}{c}\text { WID-series based on Bartels (2017) } \\
\text { that include capital gains. }\end{array}$ \\
\hline Top Income Shares without Capital Gains \\
\hline $2001-2008$ & $\begin{array}{c}\text { Series based on Bartels (2017) that exclude capital gains. } \\
\text { Micro-data exists only for the years 2001-2008. }\end{array}$ \\
\hline & Important Capital Income Tax Laws \\
\hline & Withholding tax on capital gains introduced.
\end{tabular}

\section{Denmark.}

\begin{tabular}{cc}
\hline Years & Top Income Shares with Capital Gains \\
\hline \hline $\begin{array}{c}\text { 1870-2010 } \\
\text { with interruptions }\end{array}$ & $\begin{array}{c}\text { WID-series based on Atkinson and Søgaard (2016) that } \\
\text { include capital gains but likely to be small (see page 268). }\end{array}$ \\
\hline Important Capital Income Tax Laws \\
\hline 1922-1960 \\
"Capital gains were only included if they were accrued \\
on intent (i.e., if they were accrued in relation \\
to a taxpayer's livelihood or speculation)" \\
(see Atkinson and Søgard, 2016, page 268). \\
"The treatment and placement of capital gains in \\
the tax system were changed a number of times, \\
but the changes in general kept capital gains \\
not related to a taxpayer's livelihood outside \\
the income concept used in the statistics. As a \\
consequence, we interpret the income series as excluding \\
capital gains." (see Atkinson and Søgard, 2016, page 268).
\end{tabular}


Spain.

\begin{tabular}{cc}
\hline \multicolumn{1}{c}{ Years } & Top Income Shares with Capital Gains \\
\hline \hline $\begin{array}{c}\text { 1948-2012 } \\
\text { with interruptions }\end{array}$ & $\begin{array}{r}\text { WID-series based on Alvaredo and Saez (2009) } \\
\text { that includes capital gains. }\end{array}$ \\
\hline Top Income Shares without Capital Gains \\
\hline Series that exclude capital gains \\
based on Alvaredo and Saez (2009) and \\
the update by Alvaredo and Bauluz (2014). \\
\hline Since 1979 & Important Capital Income Tax Laws \\
& $\begin{array}{c}\text { Capital gains are included in the tax base } \\
\text { (see Alvaredo and Saez (2009) for details). }\end{array}$
\end{tabular}

Finland.

\begin{tabular}{cc}
\hline \multicolumn{1}{c}{ Years } & Top Income Shares without Capital Gains \\
\hline \hline $\begin{array}{c}\text { 1920-2009 } \\
\text { With interruptions }\end{array}$ & $\begin{array}{c}\text { WID-series based on Jäentti et al. (2010) } \\
\text { that excludes capital gains. }\end{array}$ \\
\hline & Important Capital Income Tax Laws \\
\hline Since 1989 1993 & $\begin{array}{c}\text { Capital gains partly subject to taxation. } \\
\text { Capital gains taxes at the same rate as } \\
\text { other property income, imputed rents from } \\
\text { owner occupied housing exempted. }\end{array}$ \\
\hline
\end{tabular}

France.

\begin{tabular}{cc}
\hline \multicolumn{1}{c}{ Years } & \\
\hline \hline & Top Income Shares without Capital Gains \\
\hline $\begin{array}{c}\text { 1900-2013 } \\
\text { With interruptions }\end{array}$ & $\begin{array}{c}\text { WID-series based on Garbinti et al. (2018) } \\
\text { that excludes capital gains (DINA-series). }\end{array}$ \\
\hline & Top Income Shares with Capital Gains \\
\hline $\begin{array}{c}\text { 1900-2013 } \\
\text { with interruptions }\end{array}$ & Series based on Garbinti et al. (2018). \\
\hline
\end{tabular}




\section{United Kingdom.}

\begin{tabular}{|c|c|}
\hline Years & \\
\hline & Top Income Shares without Capital Gains \\
\hline \multirow{3}{*}{$\begin{array}{l}\text { 1908-2013 } \\
\text { with interruptions }\end{array}$} & WID-series based on Atkinson (2005) and update by \\
\hline & Alvaredo et al. (2018) that excludes capital gains. \\
\hline & Important Tax Laws \\
\hline Up to 1989 & $\begin{array}{l}\text { The income tax data relate to the 'tax unit', } \\
\text { which consists of a married couple, or of } \\
\text { a single adult or of a single minor with } \\
\text { income in his or her own right. }\end{array}$ \\
\hline From 1990 & $\begin{array}{l}\text { The total income is always associated } \\
\text { with the individual aged } 15 \text { years or older. }\end{array}$ \\
\hline
\end{tabular}

Italy.

\begin{tabular}{cc}
\hline Years & Top Income Shares with Capital Gains \\
\hline \hline $\begin{array}{c}\text { 1974-2009 } \\
\text { with interruptions }\end{array}$ & $\begin{array}{c}\text { WID-series based on Alvaredo and Pisano (2010) } \\
\text { which excludes most realized capital gains. }\end{array}$ \\
\hline Important Capital Income Tax Laws \\
\hline Since 1998 & $\begin{array}{r}\text { "Realized capital gains went mostly untaxed } \\
\text { Capital gains "from qualified equities have been }\end{array}$ \\
& $\begin{array}{r}\text { reported at varying degrees. Consequently, income covers } \\
\text { capital income incompletely and excludes most capital gains." } \\
\text { (see Alvaredo and Pisano, 2010, page 629). }\end{array}$ \\
\hline
\end{tabular}


Japan.

\begin{tabular}{|c|c|}
\hline Years & \\
\hline & Top Income Shares with Capital Gains \\
\hline \multirow[t]{3}{*}{$1886-2010$} & WID-series based on Moriguchi and Saez (2008) \\
\hline & which includes realized capital gains. \\
\hline & Top Income Shares without Capital Gains \\
\hline \multirow[t]{4}{*}{$1886-2000$} & Series without capital gains from \\
\hline & Moriguchi and Saez (2008) (only top1\%). \\
\hline & The series can be found at \\
\hline & https://eml.berkeley.edu/ saez/. \\
\hline \multirow[t]{2}{*}{$2001-2010$} & Update by Alvaredo et al. (2012). \\
\hline & Important Capital Income Tax Laws \\
\hline Since 1947 & Realized capital gains taxed. \\
\hline
\end{tabular}

Netherlands.

\begin{tabular}{cc}
\hline Years & \\
\hline \hline & Top Income Shares without Capital Gains \\
\hline $1920-2012$ & WID-series based on Atkinson and Salverda (2005) \\
with interruptions & that excludes capital gains. \\
\hline
\end{tabular}


Norway.

\begin{tabular}{cc}
\hline Years & Top Income Shares with Capital Gains \\
\hline \hline 1875-2011 & $\begin{array}{c}\text { WID-series based on Aaberge and Atkinson (2010) } \\
\text { that includes capital gains. }\end{array}$ \\
\hline Top Income Shares without Capital Gains \\
\hline Series without capital gains are \\
based on Alstadsæter et al. (2017). \\
Important Capital Income Tax Laws \\
\hline $\begin{array}{c}\text { Tax reform that included wide reductions } \\
\text { of taxes on capital income, resulting in } \\
\text { a spike of the top income share series } \\
\text { around this time (Fjærli and Aaberge, 2000). } \\
\text { In January 2006, Norway changed its shareholder } \\
\text { income tax code. In anticipation of the reform, } \\
\text { dividend payouts strongly increased before 2006, } \\
\text { resulting in a spike in the top income share series } \\
\text { (Alstadsæter et al., 2017). }\end{array}$ \\
\hline
\end{tabular}

\section{Portugal.}

Years

\begin{tabular}{cc}
\hline \hline & Top Income Shares with Capital Gains \\
\hline $\begin{array}{c}\text { 1936-2005 } \\
\text { with interruptions }\end{array}$ & WID-series from Alvaredo (2009) \\
& that excludes most capital gains. \\
\hline Before 1989 & Important Capital Income Tax Laws \\
Since 1989 & Interest income taxed at the source and not \\
& reported in personal tax forms. Capital gains \\
& from public bonds, most real estate, and \\
& stocks held more than 12 months exempted. \\
& Remaining capital gains on tax statements \\
likely small, see Alvaredo (2009) for details.
\end{tabular}




\section{Sweden.}

\begin{tabular}{cc}
\hline \multicolumn{1}{c}{ Years } & Top Income Shares with Capital Gains \\
\hline \hline $\begin{array}{c}\text { 1903-2013 } \\
\text { with interruptions }\end{array}$ & $\begin{array}{r}\text { WID-series based on Roine and Waldenström (2008) } \\
\text { that includes capital gains. }\end{array}$ \\
\hline $\begin{array}{c}\text { Top Income Shares without Capital Gains } \\
\text { with interruptions }\end{array}$ & $\begin{array}{c}\text { Series without capital gains are taken } \\
\text { from the website of Daniel Waldenstroem. } \\
\text { The associated data can be downloaded at } \\
\text { http:/ / www.uneconomics.se/ danielw / Data.htm. }\end{array}$ \\
\hline Important Capital Income Tax Laws \\
\hline $\begin{array}{c}\text { Tax reforms that lead to peaks in } \\
\text { income shares, in particular the one } \\
\text { that includes capital gains. }\end{array}$ \\
\hline
\end{tabular}

\section{United States.}

\begin{tabular}{cc}
\hline Years & Top Income Shares without Capital Gains \\
\hline 1913-2013 & $\begin{array}{r}\text { WID-series based on Piketty et al. (2018) } \\
\text { and Piketty and Saez (2003) that excludes } \\
\text { capital gains (DINA-series). }\end{array}$ \\
\hline Top Income Shares with Capital Gains \\
\hline References - Data Appendix
\end{tabular}

Aaberge, R. and A. Atkinson (2010). Top Incomes in Norway. in A. B. Atkinson and T. Piketty (eds.), Top Incomes: A Global Perspective, Oxford University Press, Oxford, 448-481.

Alstadsæter, A., M. Jacob, W. Kopczuk, and K. Telle (2017). Accounting for business income in measuring top income shares. Integrated accrual approach using individual and firm data from Norway. NBER Working Paper 837.

Alvaredo, F. (2009). Top incomes and earnings in Portugal 1936-2005. Explorations in Economic History 46.

Alvaredo, F., A. Atkinson, and S. Morelli (2018). Top wealth shares in the uk over more than a century. Journal of Public Economics 162, 26-47.

Alvaredo, F. and L. Bauluz (2014). Spain: Estimates of Top Income Shares 2011-12, and Revision for 20012010. Technical Notes, World Inequality Lab (4). 
Alvaredo, F., C. Moriguchi, and E. Saez (2012). Japan estimates of top income shares: update to 2010. Technical Notes, World Inequality Lab (7).

Alvaredo, F. and E. Pisano (2010). Top Incomes in Italy, 1974-2004. in A. B. Atkinson and T. Piketty (eds.), Top Incomes: A Global Perspective, Oxford University Press, Oxford.

Alvaredo, F. and E. Saez (2009). Income and Wealth Concentration in Spain in a Historical and Fiscal Perspective. Journal of the European Economic Association 7(5), 1140-1167.

Atkinson, A. (2005). Top Incomes in the UK over the 20th Century. Journal of the Royal Statistical Society 168(2), 325-343.

Atkinson, A. and A. Leigh (2007). The Distribution of Top Incomes in Australia. The Economic Record 83(262), 247-261.

Atkinson, A. and W. Salverda (2005). Top Incomes in the Netherlands and the United Kingdom over the 20th Century. Journal of the European Economic Association 3(4), 883-913.

Atkinson, A. and J. Søgaard (2016). The Long-Run History of Income Inequality in Denmark. The Scandinavian Journal of Economics 118(2), 264-291.

Bartels, C. (2017). Top Incomes in Germany, 1871-2013. World Inequality Database working paper series (18).

Burkhauser, R., M. Hahn, and R. Wilkins (2015). Measuring top incomes using tax record data: A cautionary tale from Australia. Journal of Economic Inequality 13(2), 181-205.

Decoster, A., K. Dedobbeleer, and S. Maes (2017). Using fiscal data to estimate the evolution of top income shares in Belgium from 1990 to 2013. KU Leuven Discussion Paper.

Dell, F. (2005). Top Incomes in Germany and Switzerland Over the Twentieth Century. Journal of the European Economic Association 3(2-3), 412-421.

Fjærli, E. and R. Aaberge (2000). Tax Reforms, Dividend Policy and Trends in Income Inequality: Empirical Evidence based on Norwegian Data. Discussion Paper Statistics Norway (284).

Foellmi, R. and I. Martínez (2017). Volatile Top Income Shares in Switzerland? Reassessing the evolution between 1981 and 2010. The Review of Economics and Statistics 99(5), 793-809.

Garbinti, B., J. Goupille-Lebret, and T. Piketty (2018). Income Inequality in France, 1900-2014: Evidence from Distributional National Accounts. Journal of Public Economics 162, 63-77.

Jäentti, M., M. Riiheläe, R. Sullström, and M. Tuomala (2010). Trends in Top Income Shares in Finland. in A. B. Atkinson and T. Piketty (eds.), Top Incomes: A Global Perspective, Oxford University Press, Oxford.

Moriguchi, C. and E. Saez (2008). The evolution of income concentration in Japan, 1886-2005: Evidence from income tax statistics. Review of Economics and Statistics 90(4), 713-734.

Piketty, T. and E. Saez (2003). Income Inequality in the United States, 1913-1998. The Quarterly Journal of Economics 118(1), 1.

Piketty, T., E. Saez, and G. Zucman (2018). Distributional National Accounts: Methods and Estimates for the United States. Quarterly Journal of Economics 133(2), 553-609. 
Roine, J. and D. Waldenström (2008). The Evolution of Top Incomes in an Egalitarian Society: Sweden, 1903-2004. Journal of Public Economics 92(1-2), 366-387.

Saez, E. and M. Veall (2005). The Evolution of High Incomes in Northern America: Lessons from Canadian Evidence. American Economic Review 95(3), 831-849. 